\title{
Interim Control Strategy for the Test Area North/Technical Support Facility Sewage Treatment Facility Disposal Pond - Two-year Update
}

April 2007 



\section{Interim Control Strategy for the Test Area North/Technical Support Facility Sewage Treatment Facility Disposal Pond - Two-year Update}

April 2007 



\section{ABSTRACT}

The Idaho Cleanup Project has prepared this interim control strategy for the U.S. Department of Energy Idaho Operations Office pursuant to DOE Order 5400.5, Chapter 11.3e(1) to support continued discharges to the Test Area North/Technical Support Facility Sewage Treatment Facility Disposal Pond. In compliance with DOE Order 5400.5, a 2-year review of the Interim Control Strategy document has been completed. This submittal documents the required review of the April 2005 Interim Control Strategy. The Idaho Cleanup Project's recommendation is unchanged from the original recommendation.

The Interim Control Strategy evaluates three alternatives: (1) reroute the discharge outlet to an uncontaminated area of TSF-07; (2) construct a new discharge pond; or (3) no action based on justification for continued use.

Evaluation of Alternatives 1 and 2 are based on the estimated cost and implementation timeframe weighed against either alternative's minimal increase in protection of workers, the public, and the environment. Evaluation of Alternative 3, continued use of the TSF-07 Disposal Pond under current effluent controls, is based on an analysis of four points:

- Record of Decision controls will protect workers and the public

- Risk of increased contamination is low

- Discharge water will be eliminated in the foreseeable future

- Risk of contamination spread is acceptable.

The Idaho Cleanup Project recommends Alternative 3, no action other than continued implementation of existing controls and continued deactivation, decontamination, and dismantlement efforts at the Test Area North/Technical Support Facility. 


\section{CONTENTS}

ABSTRACT iii

ACRONYMS vii

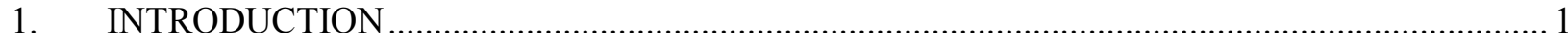

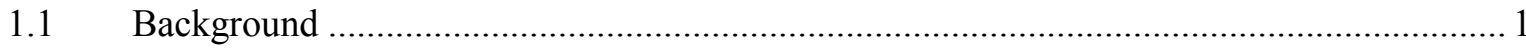

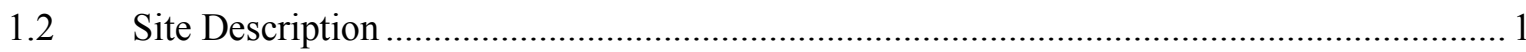

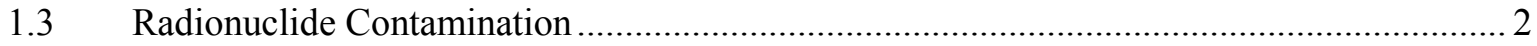

2. INTERIM CONTROL STRATEGY ALTERNATIVES …..................................................... 4

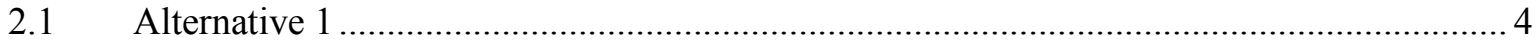

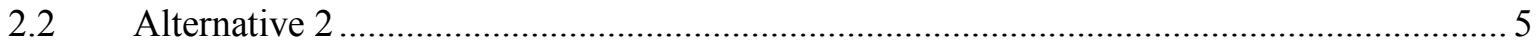

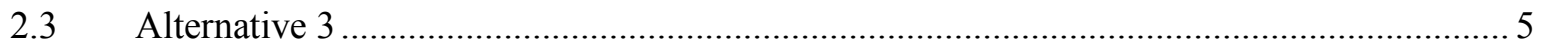

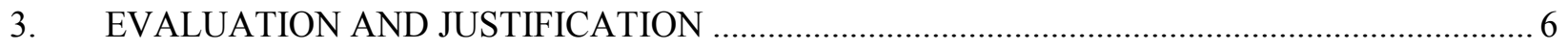

3.1 Record of Decision Controls Will Protect Workers and the Public ................................... 6

3.2 Risk of Increased Contamination is Low ............................................................... 7

3.3 Discharge Water Will Be Eliminated in the Foreseeable Future....................................... 8

3.4 Risk of Contamination Spread is Acceptable .............................................................. 9

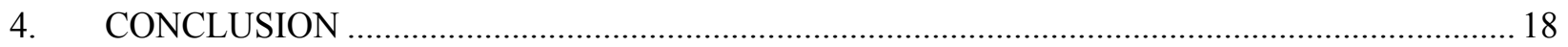

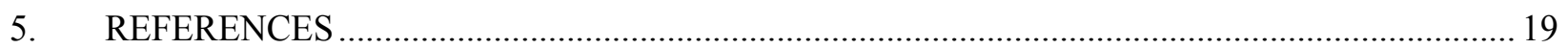

Appendix A, TSF-07 Background from the Remedial Investigation/Feasibility Study ......................... A-1

Appendix B, Technical Support Facility Discharge Sources............................................................ B-1

Appendix C, Semi-Analytical Model for the Assessment of the Groundwater Pathway from the Leaching of Surficial and Buried Contamination and Release of Contaminants from Percolation Ponds 


\section{FIGURES}

3-1. Test Area North/Technical Support Facility injection well/ trichloroethylene plume location ..... 14

\section{TABLES}

3-1. GWSCREEN model parameter values used to simulate radionuclide transport from the TSF-07 Pond to the Snake River Plain Aquifer. 10

3-2. Radiological contaminant-specific parameter used.

3-3. Results for 9/02 GWSCREEN simulation of radionuclide transport from the TAN/TSF Sewage Treatment Disposal Pond.

3-4. Sample results from groundwater monitoring Well TAN-10A. 16 


\section{ACRONYMS}

CERCLA Comprehensive Environmental Response, Compensation, and Liability Act

COC contaminant of concern

DCG Derived Concentration Guide

DD\&D deactivation, decontamination, and dismantlement

DOE-ID U.S. Department of Energy Idaho Operations Office

IC institutional control

ICP Idaho Cleanup Project

ICS interim control strategy

LOFT Loss-of-Fluid-Test

MCL maximum contaminant level

$\mu \mathrm{Ci} / \mathrm{mL} \quad$ microcuries pre milliliter (10.E-6)

OU operable unit

$\mathrm{pCi} / \mathrm{L} \quad$ picocuries pre liter (10.E-12)

RD/RAWP Remedial Design/Remedial Action Work Plan

RI/FS remedial investigation/feasibility study

ROD Record of Decision

STF Sewage Treatment Facility

TAN Test Area North

TSF Technical Support Facility

WAG waste area group

WLAP Wastewater Land Application Permit 


\section{Interim Control Strategy for the Test Area North/Technical Support Facility Sewage Treatment Facility Disposal Pond - Two-Year Update}

\section{INTRODUCTION}

\subsection{Background}

Treated sewage effluent and process drain wastewater from the Test Area North (TAN) Technical Support Facility (TSF) and low-level radioactive liquid waste have been discharged into the TAN/TSF Sewage Treatment Facility (STF) Disposal Pond since 1972. The disposal pond has operated under a Wastewater Land Application Permit (WLAP) since 1996. Wastewater discharges since April 2005 did not contain radionuclides above drinking water maximum contaminant levels (MCLs), as demonstrated through routine sampling. However, the soil column associated with the disposal pond is contaminated from historical low-level radioactive wastewater discharges.

DOE Order 5400.5, "Radiation Protection of the Public and the Environment," states that "the use of soil columns (i.e., ponds) to retain, by sorption or ion exchange, suspended or dissolved radionuclides from liquid waste streams shall be discontinued at the earliest practicable time in favor of an acceptable alternative disposal means" (DOE O 5400.5, II.3b[1]), and further states that "liquid discharges, even though uncontaminated, are prohibited in inactive release areas to prevent the further spread of radionuclides previously deposited" (DOE O 5400.5, II.3c[2]). The Idaho Cleanup Project (ICP) has prepared this Interim Control Strategy (ICS) for the U.S. Department of Energy Idaho Operations Office (DOE-ID) pursuant to DOE Order 5400.5, Chapter II.3e(1) to support continued discharges to the disposal pond. The order also requires a 2-year review of the ICS. This submittal documents the review and provides available updated information.

\subsection{Site Description}

The TAN/TSF STF Disposal Pond is a 35-acre unlined, bermed pond constructed in 1971, located southwest of the TSF area. It began receiving wastewater in September 1972. Most of the disposal pond is dry and has never received liquid effluent. The active portion of the disposal pond consists of a primary disposal area ( 0.9 acres) and an overflow section $(0.33$ acres $)$ in the northeastern section. This active area was larger in the past when effluent flow rates were higher, but does not appear to have exceeded 5 acres (see Appendix A). The overflow pond rarely has been used.

The disposal pond received wastewater from a variety of sources, including sanitary waste discharges, low-level radioactive waste, cold process water, and treated sewage effluent. It regularly receives effluent from two sources: the TSF sewage system and TSF process drains. Sanitary waste, which is treated prior to release, consists primarily of wastes from rest rooms, sinks, and showers from office/personnel areas. Process drain effluent consists of industrial effluent, primarily steam condensate and boiler blowdown, water softener and demineralizer discharges, and cooling, heating, and air conditioning water. Process drain effluent commingles with treated sanitary waste at the Liquid Waste Lift Station (TAN-655) and is discharged to the disposal pond. 


\subsection{Radionuclide Contamination}

The 35-acre TAN/TSF STF Disposal Pond area is designated as TSF-07 in Waste Area Group (WAG) 1, Operable Unit (OU) 1-10 (TSF-07 was originally in OU 1-06).

The Comprehensive Remedial Investigation/Feasibility Study for the Test Area North Operable Unit 1-10 at the INEL (RI/FS; DOE-ID 1997) evaluated the results of sampling for environmental characterization of contaminants, including radionuclides. In accordance with the RI/FS, approximately 5 acres associated with the active area (northeastern corner and eastern edge) are contaminated with radionuclides, metals, and organics. Characterization sampling identified a body of perched water in the surficial sediments below the active area of the disposal pond. The perched water is attributed to the discharge of wastewater. Historical information on the sources of radioactivity in the disposal pond is minimal. The process and sanitary drain system serviced some buildings, such as TAN-607, which have supported radiological activities. Lightly borated water was transported from the Loss-of-Fluid Test (LOFT) facility when it was operational to a manhole in the process waste line just upstream of the TAN-655 sump. Each discharge from LOFT was verified to meet the concentration limits for releases to uncontrolled areas, as specified in 10 CFR 20 (see Appendix B). The deactivation, decontamination, and dismantlement (DD\&D) work at LOFT (TAN-630 and TAN-650) was completed in 2006. Discharges from the TAN/TSF area have been monitored since 1986. Outside of the 5-acre contaminated area, as stated in the RI/FS, "No radioactivity above background values was detected in a field survey of the western half of the TSF-07 pond performed in 1993. These results are interpreted to indicate that this end of the pond has not been used and that contaminants are not migrating horizontally from the contaminated eastern end of the pond" (see Appendix A). NOTE: Appendix A has not changed from the original document, other than to revise the treatment for the V-tanks, which does not impact this report.

Approximately 10 acres in the western third of the disposal pond are separated by a berm from the remainder of the pond. This area was designated as a "Wastewater Disposal Area for Comprehensive Environmental Response, Compensation, and Liability Act (CERCLA) actions." In 1994, the southeastern corner of this CERCLA disposal area, with appropriate approvals, was used for percolation of effluent from the "pump and treat" action located near the TAN/TSF injection well. About 336,000 gallons was pumped from the pump and treat unit to the disposal pond over a 6-month period. Approximately 240 microcuries of Sr-90 and 275 microcuries of Cs-137 were in the effluent (INEL 1995). The area affected is less than an acre. No standing water was produced.

The RI/FS states: "As concluded in the evaluation of historical and analytical data on the TAN TSF-07 Disposal Pond (Medina 1993), Co-60, Cs-137, Cs-134, strontium (total), Am-241, Eu-155, and tritium were detected in the pond sediments and shallow subsurface soils at the site. Additionally, Co-60 and Cs-137 were detected in the subsurface soil from 3 to $3.4 \mathrm{~m}$ below ground surface. Surface water sample results indicated the presence of Am-241, Co-60, Cs-137, strontium (total), and tritium. Strontium-90 has been detected in the perched water with concentrations ranging from 1.0 to 136 picocuries per liter $(\mathrm{pCi} / \mathrm{L})$. The average $\mathrm{Sr}-90$ concentration in the perched water was approximately $13 \mathrm{pCi} / \mathrm{L}$ (Medina 1993)" (DOE-ID 1997, page 4-105). See Appendix A, which reproduces the discussion of the site, previous investigations, and nature and extent of contamination in TSF-07 from the RI/FS, for more information.

The DOE Final Record of Decision for Test Area North (ROD) (DOE-ID 1999) concluded in Part II, Section 8.2.1.2, "Human Health Risks": "The exposure route and the associated contaminants of concern (COCs) that produce calculated risks greater than 1 in 10,000 at the site are external radiation exposure of current workers by Cs-137 and external radiation exposure of future residents by Cs-137." The Ecological Risk Assessment in the ROD (Section 8.2.1.3) concluded that there is "an ecological risk (i.e., the HI) greater than the threshold level of 1 from arsenic, mercury, tetrahydrofuran, and thallium." 
Radionuclides are not identified as contributing to this ecological risk rating. The radionuclides not selected as COCs have either short half-lives or were not present in sufficient concentrations to merit COC status.

The WLAP Renewal Application, issued in October 2000 (INEEL 2000a), updated and LA-000153-02 issued in January 2005, and modified in October 2005 (Johnston 2005), assessed previous radionuclide monitoring data for the disposal pond. Gross alpha was detected from 1996 through 2006, but the "annual average gross alpha results were well below the drinking water MCL of $15 \mathrm{pCi} / \mathrm{L}$. The gross alpha historical maximum was also well below the drinking water MCL (ICP 2006, page 5-15)." Sr-90 was detected in March and April of 2005. CS-137 was detected in one March 2005 sample. No other detections of Sr-90 or Cs-137 occurred in 2005 or 2006. Sr-89, tritium, and I-129 were not detected in effluent monitoring during 2005 or 2006.

Strontium-90 activity levels in TAN-655 effluent exceeded the $8.0-\mathrm{pCi} / \mathrm{L}$ drinking water MCL once during the period January 2005 to October 2006 (ICP 2005, 2006). This event occurred in March 2005 in a duplicate sample $(14.4 \mathrm{pCi} / \mathrm{L})$. There were two other Sr-90 detections during this same 2-year timeframe that did not exceed the MCL, which were in March 2005 (5.00 pCi/L) and April 2005 (7.28 pCi/L). Sr-90 levels were nondetects for all other months during 2005 and 2006. 


\section{INTERIM CONTROL STRATEGY ALTERNATIVES}

The objective of this ICS is to document how ICP will achieve compliance with DOE Order 5400.5 (i.e., cessation of liquid effluent to the contaminated soil column). Immediate elimination of the liquid effluent to the contaminated soil is not warranted due to current and anticipated operations at TAN/TSF. The TAN/TSF area has undergone significant reduction in activities, and a DD\&D footprint reduction closure plan was developed that addresses DD\&D actions to date (ICP 2003).

For the interim period until effluent discharges to the disposal pond are eliminated, two alternatives have been considered to reduce the impact of the discharges on the soil column. A third alternative, the selected alternative, addresses continued use of the disposal pond with no additional action. Costs for the first two alternatives have not been determined by a formal engineering study/cost analysis. The cost figures given are rough orders of magnitude. All three alternatives assume existing controls on restricting radionuclide-contaminated discharges to drinking water MCLs at the disposal pond will continue as long as the disposal pond is in operation.

The three alternatives are:

1. Reroute the discharge outlet to an uncontaminated area of TSF-07

2. Construct a new discharge pond

3. No action.

\subsection{Alternative 1}

Alternative 1 would reroute the discharge outlet for the disposal pond to an uncontaminated area of TSF-07. Currently the western half of TSF-07 is uncontaminated by radionuclides or nonradionuclide contaminants, except for the section used in the "pump and treat" action discussed previously. However, the area affected is minimal and would easily allow a 5-acre area (twice the size of the current active disposal pond) to be designated in the center or western portion of the 35-acre bermed area for receipt of wastewater. This alternative would require the following activities:

- $\quad$ Sampling to confirm that the area selected is indeed free of radionuclides and other contaminants.

- $\quad$ Construction of either a pipe or lined ditch from the current outlet to the new location in TSF-07, a distance of approximately 1,200 to $2,000 \mathrm{ft}$. Potentially, the line used to transport "pump and treat" effluent could be used with extensions. The pipe is above ground and heat-traced but is in disrepair and will require maintenance.

- Soil removal to allow for sedimentation.

- $\quad$ Construction of a berm to separate the new active area from the remainder of TSF-07 to prevent overflow into the contaminated soil column area or "pump and treat" area, as needed.

- $\quad$ Revision to the WLAP, if required by the state.

Estimated costs for this work are in the range of $\$ 250 \mathrm{~K}$ to $\$ 500 \mathrm{~K}$, and would require approximately 18 months after a final decision is made to design and construct and to revise environmental documents, if required. 


\subsection{Alternative 2}

A new disposal pond could be constructed to remove the effluent discharge from the TSF-07 area. A potential location is directly south of the TAN-655 Lift Station and TAN/TSF-05 Injection Well (closed) and east of the TSF-07. The injection well plume extends east before moving south, which would allow for a new disposal pond. The area to the west of the disposal pond could also be considered. This alternative would require the following activities:

- Characterization sampling to confirm area is uncontaminated

- $\quad$ Removal of surface soil to create and berm the pond

- Construction of a pipe or lined ditch or pipe from the current outlet to the new pond

- $\quad$ Revision of the WLAP.

Estimates for this work are in the range of $\$ 500 \mathrm{~K}$ to $\$ 1,000 \mathrm{~K}$, and would require approximately 24 months after a final decision is made to design and construct and to revise environmental documents.

\subsection{Alternative 3}

The third alternative is to continue discharges until the TAN/TSF STF is no longer required to support operations. This alternative requires no action be taken beyond the controls imposed by the ROD. The evaluation of Alternative 3, continued discharge under current controls, is presented in Section 3. 


\section{EVALUATION AND JUSTIFICATION}

Alternatives 1 and 2 would result in the elimination of effluent discharges to the contaminated soil column, as required by DOE Order 5400.5. The soil column would stabilize as the perched water body below the active portion of the disposal pond dissipates, removing the risk of the Cs-137 and Sr-90 migration vertically toward the aquifer or laterally into uncontaminated areas. Compliance with DOE Order 5400.5 possibly could be achieved within 2 years after a final decision is made. However, both alternatives involve significant costs and possible revision of existing environmental documents, as well as documentation of the new action through the National Environmental Policy Act (42 USC $\S 4321$ ) process. Each alternative would also require further evaluation to ensure that the new disposal areas are sufficiently distant from the contaminated area of TSF-07 that any newly created perched water body would not impact the contaminated soil column. Alternatives 1 and 2 also would require coordination with the OU 1-07B remediation project to ensure that changes in recharge related to current wastewater disposal practices do not negatively impact the OU 1-07B CERCLA action.

Alternative 3 also achieves compliance with the DOE order, but over a longer period as TAN/TSF activities are phased out. Discharges would continue to the contaminated soil column at the current, or more likely, at a lower rate, as buildings are closed at TAN. However, ICP believes the impact of continued discharges will be low, and recommends Alternative 3 for DOE approval. This recommendation is based on an evaluation of the following points:

- $\quad$ ROD administrative controls will protect workers and the public

- $\quad$ Risk of increased contamination is low

- $\quad$ Discharge water will be eliminated in the foreseeable future

- $\quad$ Risk of contamination spread is acceptable

The evaluation of each of these points follows.

\subsection{Record of Decision Controls Will Protect Workers and the Public}

The ROD for the TAN/TSF STF Disposal Pond (DOE-ID 1999) documents a human health risk to Cs-137 based on external exposure to workers and future residents No other radionuclides exceeded the ROD screening thresholds. The ROD evaluated three remediation alternatives: (1) limited action, (2) containment, and (3) excavation and disposal.

The selected remedy from the 1999 TAN ROD for TSF-07 was "Limited Action." The remedy included soil sampling, inspecting existing operational controls, implementing additional institutional controls as needed, and environmental monitoring for at least 100 years. The remedial design and remedial action work plan (RD/RAWP) established the requirements for this site and were addressed in the Group 1 RD/RAWP (DOE-ID 2002), which was originally issued in August 2000.

The primary limited action steps developed for the TSF-07 site, as addressed in the Group 1 RD/RAWP, were as follows:

- $\quad$ Existing administrative and institutional controls will be evaluated, and if deemed appropriate, will be revised with new, upgraded practices and controls. 
- $\quad$ Radiological surveys around the perimeter of the disposal pond will be conducted annually, and sampling for Cs-137 will be conducted in 2071 to verify the site is available for unrestricted land use.

- New warning signs will be attached to the radiation control fence around the perimeter of the disposal pond.

The Group 1 RD/RAWP indicated that the limited actions for the TSF-07 Disposal Pond would be implemented through the Waste Area Group (WAG) 1 Institutional Controls (IC) Plan (INEEL 2000b) and the OU 1-10 Operations and Maintenance (O\&M) Plan (DOE-ID 2001a). The WAG 1 IC Plan identified the necessary institutional controls for the TSF-07 pond including signage, control of activities, and identification of the site and restrictions in the Idaho National Engineering Laboratory Comprehensive Facility and Land Use Plan (DOE-ID 1996). The OU 1-10 O\&M Plan identified the necessary environmental monitoring for the TSF-07 pond, including an annual radiological survey around the site perimeter and sampling for releasing land-use restrictions in year 2071. The year 2071 represents the anticipated year when the concentrations of Cs- 137 will have decayed to below $2.3 \mathrm{pCi} / \mathrm{g}$, which is the level required for unrestricted land use.

In addition to the limited action remedy elements addressed previously, the 1999 TAN ROD also indicated that "A 1-ha (2.5-acre) portion of the pond is still in use and will undergo assessment when operations cease." The pond is currently expected to continue to be used into 2008, when TSF area DD\&D activities are complete. The activity to perform this assessment will, therefore, be incorporated into the INL Sitewide Operations and Maintenance Plan for CERCLA Response Actions (DOE-ID 2004). This CERCLA assessment will require coordination with the closure of the pond per the wastewater land application permit (DOE-ID 2006a).

Administrative controls for all of WAG 1 are addressed in the INL Sitewide Institutional Controls Plan (DOE-ID 2006b). In addition to the controls listed previously, the plan includes the control requirements, "control of activities (RWP, STD-101)" and "published surveyed boundaries and description of controls in the INEEL Land Use Plan."

The administrative controls are assessed annually. The Idaho National Laboratory (INL) Sitewide Institutional Controls Annual Report - FY 2006 (FY-06) was issued in August 2006 (DOE-ID 2006c). The report showed that the various institutional control measures in place across the Idaho National Laboratory Site, such as TSF-07, are functioning as intended.

\subsection{Risk of Increased Contamination is Low}

Risk of additional contamination is specifically addressed in the annual status updates for implementing best available technology for control of radioactive materials in liquid waste streams, as required by DOE Order 5400.5, Chapter II.3.b.(1). The TAN/TSF STF Disposal Pond is included in this report because the best available technology selection process applies to those liquid waste streams that will continue to be discharged to soil columns for indefinite periods and that may contain process-derived radionuclides.

The 2004 Status Update for Implementing BAT states, "However, some residual radioactive contamination may be in the TAN/TSF process wastewater lines, which could result in some continued radiological contaminant discharges to the Sewer Treatment Plant and Disposal Pond" (ICP 2004, page 17). There is also "the potential (although small) for inadvertent releases (e.g. equipment failures) of radionuclides" (ICP 2004, page 4). "In addition, this facility may be used for disposal of individual waste 
streams containing process-derived radionuclides. Only those individual waste streams that have received the appropriate approval may be discharged" (ICP 2004, page 21).

Waste Generator Services is required to evaluate all new discharges to the environment to ensure they are in compliance with DOE Order 5400.5 and other regulations. This process is in effect for the TAN/TSF STF. In 2000, water with radionuclide concentrations above MCLs was treated, and with DOE-ID approval, discharged to the disposal pond (ICP 2004, page 21).

Radiological sample results documented in the status update confirm that "the discharges to the TAN/TSF STF Disposal Pond are typically below MCLs. However, elevated levels (above $8 \mathrm{pCi} / \mathrm{L}$ ) of strontium-90 were detected in one of the monthly samples between January 2005 and October 2006. There is a low, but potential, risk for an inadvertent release of contamination. The RI/FS evaluated "co-located facilities" in Section 8.4.11 to address the potential of "past and present activities associated with TAN facilities and structures. . f for causing current risk to be underestimated" (DOE-ID 2001b). This analysis considered the Hot Shop Facility (TAN-607) and the Radioactive Liquid Waste Treatment and Transfer/Storage buildings (TAN-616 and -666) as the only TSF facilities "identified to have the potential to produce unacceptable future risks at WAG 1" (DOE-ID 2001b). This analysis did not identify any under-estimated risk based on facility design and administrative controls.

TAN-616 has been isolated and the building removed. TAN-666 has been removed. These types of actions are further reducing the risk of inadvertent contamination. Appendix B lists the TSF discharge sources as of 2006, based on the 2006 Liquid Effluent Inventory, and included in the STF WLAP. Since the original list was prepared, the following buildings no longer discharge to the STF system: TAN-601 Guardhouse, TAN-607 Decontamination Shop, and TAN-603 Service.

The potential for inadvertent radionuclide contamination is highest in those buildings supporting radioactive materials/processes with process drains or showers that could be used for personnel decontamination. Two such buildings are listed in Appendix B: (1) TAN-607, containing the assembly area, storage areas, hot shops, and cells; and (2) TAN-633 Hot Cell Annex. TAN-633 has been inactivated. The project to remove the last fuel stored in TAN-607, the LOFT fuel, was completed in September 2002 and the complex decommissioned and dismantled in 2006. TAN-607 was deactivated in fall 2006 and dismantlement is scheduled for completion in spring 2008. Process drains in the floors have been capped or are controlled for cold waste only. As stated in the Best Available Technology Report and confirmed by discussions with radiological engineering, environmental, and operations personnel at TAN, the risk of inadvertent contamination to the disposal pond from TAN-607 or other TSF buildings through the process drain system is low and is decreasing as TAN activities are shut down.

\subsection{Discharge Water Will Be Eliminated in the Foreseeable Future}

Current estimates indicate TAN/TSF closure could be as early as 2008, but there is a high probability that STF discharges will not be eliminated until 2012. A footprint reduction closure plan is being developed by DD\&D to support funding requests. TAN has already downsized from an active continuous work force of approximately 360 personnel to an approximate continuous force of 120 personnel. Sewage Treatment Facility discharges vary seasonally, but currently average 32,970 gallons per day. The RI/FS and the ROD do not identify any adverse consequences of discharge of wastewater at current levels. This discharge amount is expected to decrease, but not until additional building closures reduce the requirement for steam heat and other utilities at TSF, which contribute a larger share of effluent than sanitary waste.

Although unlikely, if a decision is made to locate a major new facility or operation at TAN intended for long-term operation, the TAN STF would probably be judged inadequate and would be 
replaced. If this were to occur, a new disposal pond could be constructed, which would eliminate the requirement for this ICS.

\subsection{Risk of Contamination Spread is Acceptable}

There is a potential that existing radiological contaminants in the disposal pond could be spread by the continued addition of wastewater to the TSF-07 pond. The existing radiological contaminants could be spread as follows: (1) the addition of effluent to the disposal pond could enlarge the existing contaminated soil column and perched water body, or create additional water bodies, mobilizing contaminants horizontally into the surrounding soil, or (2) the addition of effluent to the disposal pond could cause vertical migration of contaminants from the perched water body as it dissipates into the underlying sediments and basalt, and eventually into the Snake River Plain Aquifer.

Horizontal migration of the contaminants due to expansion of the perched water body is unlikely. The perched water body (or bodies, if undetected areas of perched water exist) most likely has stabilized over time, probably well over 10 years ago during disposal pond peak usage, until a sufficient size was reached to allow the amount of water infiltrating the underlying basalt to equal the amount of effluent entering the perched water body. With the stable, or decreasing, effluent rates projected for the next 10 years, the perched water body will likely stay the same size or decrease in size relative to historical dimensions. Thus, given the decreasing activity at TAN, contaminants have not or will not likely mobilize horizontally beyond the historically contaminated area of the disposal pond.

Over time, effluent will migrate vertically, either directly into the underlying basalt or via the perched water body, and eventually into the Snake River Plain Aquifer. A model pertaining to the vertical migration of the radiological contaminants from the disposal pond, based on current effluent flow rates, was developed using GWSCREEN Version 2.5a (Rood 2002) (see Appendix C), a semi-analytical model for the assessment of the groundwater pathway from the leaching of surficial and buried contamination and release of contaminants from percolation ponds. The input parameters used for the model are given in Table 3-1. NOTE: This information has not been updated.

The radionuclide contaminants associated with the disposal pond sediments and identified for the model are Cs-137, Co-60, and Sr-90. The radiological contaminant-specific parameters used in the model are given in Table 3-2.

To produce conservative estimates of contaminant migration from the pond, GWSCREEN parameters for the pond conceptual model, the pond source term, and transport from the pond to the aquifer were assigned conservatively. Actual measured values were used where known, e.g., for the pond dimensions, aquifer flow direction and velocity, and others shown in Table 3-1. Model-calculated values were used as appropriate where measured values were not available, e.g., for longitudinal and transverse dispersion, as described in INEEL (2002). 
Table 3-1. GWSCREEN model parameter values used to simulate radionuclide transport from the TSF-07 Pond to the Snake River Plain Aquifer.

\begin{tabular}{|c|c|c|c|}
\hline Parameter & Value & Reference & Comments \\
\hline \multicolumn{4}{|l|}{ Conceptual Model } \\
\hline $\begin{array}{l}\text { Length parallel to } \\
\text { groundwater flow }\end{array}$ & $38 \mathrm{~m}$ & INEEL 2000a & $\begin{array}{l}\text { Measured from map } \\
\text { dimensions }\end{array}$ \\
\hline $\begin{array}{l}\text { Width perpendicular } \\
\text { to groundwater flow }\end{array}$ & $95 \mathrm{~m}$ & INEEL 2000a & $\begin{array}{l}\text { Measured from map } \\
\text { dimensions }\end{array}$ \\
\hline $\begin{array}{l}\text { Thickness of pond } \\
\text { sediments }\end{array}$ & $1.0 \mathrm{~m}$ & DOE 1994 & $\begin{array}{l}\text { Default value used in } \\
\text { Track } 2 \text { assessments }\end{array}$ \\
\hline $\begin{array}{l}\text { Liquid effluent flow } \\
\text { rate }\end{array}$ & $3.81 \mathrm{E}+04 \mathrm{~m}^{3} / \mathrm{yr}$ & INEEL 2000a & Measured value \\
\hline $\begin{array}{l}\text { Operation time of } \\
\text { pond }\end{array}$ & $\begin{array}{l}\text { Assumed to receive } \\
\text { water at current } \\
\text { (INEEL 2000a) rates } \\
\text { throughout period of } \\
\text { simulation ( } 1,000 \text { years) }\end{array}$ & $\begin{array}{l}\text { Conservative } \\
\text { assumption }\end{array}$ & $\begin{array}{l}\text { Maintaining constant } \\
\text { inflow results in more rapid } \\
\text { contaminant flux to aquifer, } \\
\text { less time for decay }\end{array}$ \\
\hline \multicolumn{4}{|l|}{ Transport } \\
\hline $\begin{array}{l}\text { Unsaturated } \\
\text { thickness }\end{array}$ & $27.9 \mathrm{~m}$ & $\begin{array}{l}\text { Medina } 1993 \\
\text { DOE } 1994\end{array}$ & $\begin{array}{l}\text { Site-specific estimate, } \\
\text { includes } 48 \mathrm{ft}(14.6 \mathrm{~m}) \text { of } \\
\text { silt loess underlying the } \\
\text { pond identified in } \\
\text { Medina (1993) to combined } \\
\text { estimated sedimentary } \\
\text { interbed thickness of } \\
13.25 \mathrm{~m} . \text { Basalts are not } \\
\text { included in the calculation. }\end{array}$ \\
\hline $\begin{array}{l}\text { Bulk density- } \\
\text { sediment and aquifer }\end{array}$ & $2.0 \mathrm{~g} / \mathrm{cm}^{3}$ & DOE-ID 1994 & $\begin{array}{l}\text { Default value used in } \\
\text { Track } 2 \text { assessments }\end{array}$ \\
\hline $\begin{array}{l}\text { Background } \\
\text { percolation rate }\end{array}$ & $0.1 \mathrm{~m} / \mathrm{yr}$ & DOE-ID 1994 & $\begin{array}{l}\text { Default value used in } \\
\text { Track } 2 \text { assessments }\end{array}$ \\
\hline Aquifer thickness & $76 \mathrm{~m}$ & INEEL 2000a & Site-specific value \\
\hline Vertical dispersion & 3-D averaged solution & Rood 2002 & $\begin{array}{l}\text { Assumes vertical mixing } \\
\text { over the well screen length }\end{array}$ \\
\hline
\end{tabular}


Table 3-1. (continued).

\begin{tabular}{|c|c|c|c|}
\hline Parameter & Value & Reference & Comments \\
\hline $\begin{array}{l}\text { Longitudinal and } \\
\text { transverse dispersion }\end{array}$ & $\begin{array}{l}\text { Model-calculated; } \\
\text { spatially variable based } \\
\text { on scale }\end{array}$ & Rood 2002 & $\begin{array}{l}\text { Based on regression } \\
\text { equations relating } \\
\text { dispersivity to field scale } \\
\text { size; used because no } \\
\text { site-specific values are } \\
\text { available. Based on } \\
\text { discussion in INEEL } 2002 \\
\text { this scale-dependant } \\
\text { approach is likely more } \\
\text { accurate than use of INEEL } \\
1994 \text { default parameters }\end{array}$ \\
\hline $\begin{array}{l}\text { Aquifer direction of } \\
\text { flow }\end{array}$ & 115 degrees & $\begin{array}{l}\text { Kaminski et al. } \\
1993\end{array}$ & Site-specific value \\
\hline Aquifer porosity & 0.01 & Sorenson 2000 & Site-specific value \\
\hline Darcy velocity & $1.79 \mathrm{~m} / \mathrm{yr}$ & Sorenson 2000 & Site-specific value \\
\hline Aquifer pore velocity & $179 \mathrm{~m} / \mathrm{yr}$ & Sorenson 2000 & Site-specific value \\
\hline $\begin{array}{l}\text { Contaminant } \\
\text { partition coefficients }\end{array}$ & See Table 3-2 & DOE-ID 1994 & $\begin{array}{l}\text { Default value used in Track } \\
2 \text { assessments }\end{array}$ \\
\hline \multicolumn{4}{|l|}{ Source term } \\
\hline $\begin{array}{l}\text { Contamination in } \\
\text { pond sediments }\end{array}$ & See Table 3-2 & Medina 1993 & $\begin{array}{l}\text { Conservative estimates, } \\
\text { based on maximum } \\
\text { concentrations reported } \times \\
\text { volume of sediments } \\
(\mathrm{L} \times \mathrm{W} \times \mathrm{D} \times \text { bulk density } \\
\times \text { max. concentration })\end{array}$ \\
\hline $\begin{array}{l}\text { Contaminants in pond } \\
\text { influent }\end{array}$ & 0 for all & & $\begin{array}{l}\text { Current discharges } \\
\text { reportedly do not contain } \\
\text { radionuclides }\end{array}$ \\
\hline
\end{tabular}

Table 3-2. Radiological contaminant-specific parameter used.

\begin{tabular}{|c|c|c|c|c|}
\hline Radionuclide & $\begin{array}{l}\text { Source term } \\
\text { concentrations } \\
(\mathrm{pCi} / \mathrm{g})^{\mathrm{a}}\end{array}$ & $\begin{array}{l}\text { Source term } \\
\text { activity } \\
(\mathrm{Ci})^{\mathrm{b}}\end{array}$ & $\begin{array}{l}\text { Contaminant } \\
\text { half-life } \\
(\mathrm{yr})\end{array}$ & $\begin{array}{l}\text { Contaminant Kc } \\
(\mathrm{mL} / \mathrm{g})^{\mathrm{c}}\end{array}$ \\
\hline Cs-137 & 127 & $9.17 \mathrm{E}-01$ & 30.0 & 500 \\
\hline Co-60 & 87.8 & $6.33 \mathrm{E}-01$ & 5.26 & 10 \\
\hline Sr-90 & 3.0 & $2.17 \mathrm{E}-02$ & 28.1 & 24 \\
\hline \multicolumn{5}{|c|}{$\begin{array}{l}\text { a. Maximum concentrations reported in Medina }(1993) \text {. } \\
\text { b. Source term activities calculated from disposal pond dimensions }(38 \mathrm{~m} \times 95 \mathrm{~m}) \text {, sediment thickness }(1 \mathrm{~m}) \text {, bulk density } \\
\left(2.0 \mathrm{~g} / \mathrm{cm}^{3}\right) \text {. } \\
\text { c. DOE-ID }(1994) \text {. }\end{array}$} \\
\hline
\end{tabular}


Conservative parameter value estimates were used if measured or model-calculated parameter values were unavailable. Conservative estimates were obtained either from DOE-ID (1994) or through calculations. Conservative estimates obtained from DOE (1994) included Kd (radionuclide distribution coefficients measurement) values for Cs-137, Co-60 and Sr-90. These estimates are all at the low end of ranges of values found in the literature and are typical for Idaho National Laboratory Site or Hanford basalts. The conservatism of their use in this model formulation is compounded because these values are assigned to only the combined thickness of the unsaturated zone interbed and surficial deposits, not to the total unsaturated thickness. The materials comprising the interbeds and surficial deposits contain significant clay content, and Kds are likely orders of magnitude higher than the default (basalt) values used.

Conservative values were also applied to the pond operating conditions and source term. The pond was conservatively assumed to continue to receive clean effluent throughout the period of the simulation, i.e., 1,000 years. This results in maximum driving force and contaminant migration rates to the aquifer, and minimum decay. The source term was conservatively estimated by applying the maximum measured concentrations of the contaminants of concern in pond sediments reported in Medina (1993) to the entire sediment volume. The pond conceptual model, transport model, and source term models are all, therefore, conservatively formulated, and the results are conservative estimates of contaminant flux from the pond to the aquifer.

The results of the model are given in Table 3-3, and indicate that the radiological contaminants will migrate to the Snake River Plain Aquifer at concentrations below contract-required detection limits and well below Environmental Protection Agency Primary Drinking Water Standards (40 CFR 141). As shown in Table 3-3, the model predicts that Cs-137 will not migrate either below the center of the TAN/TSF STF Disposal Pond or in the groundwater at two monitoring well locations. The model predicts that Co-60 will migrate below the center of the TAN/TSF STF Disposal Pond after 58 years with an activity of $0.0156 \mathrm{pCi} / \mathrm{L}$, and to the groundwater at monitoring Well TAN-10A after 160 years with an activity of $2.66 \mathrm{E}-13 \mathrm{pCi} / \mathrm{L}$. Further, Sr-90 is predicted to migrate below the center of the TAN/TSF STF Disposal Pond after 140 years with an activity of $0.0155 \mathrm{pCi} / \mathrm{L}$, and to the groundwater at monitoring Well TAN-10A after 525 years with an activity of $2.26 \mathrm{E}-9 \mathrm{pCi} / \mathrm{L}$. These predicted activities are well below any regulatory limits and, in fact, are below the method detection limits as shown in Table 3-3. The predicted activities are highly conservative for the reasons discussed previously. 
Table 3-3. Results for 9/02 GWSCREEN simulation of radionuclide transport from the TAN/TSF Sewage Treatment Facility Disposal Pond.

\begin{tabular}{|c|c|c|c|c|}
\hline Monitoring location & Reporting parameter & Cs-137 & Co-60 & Sr-90 \\
\hline \multirow[t]{2}{*}{ TAN-10A } & Time to peak (yr) & 0.00 & 160 & 525 \\
\hline & Peak concentration $(\mathrm{pCi} / \mathrm{L})$ & 0.00 & $2.66 \mathrm{E}-13$ & $2.26 \mathrm{E}-09$ \\
\hline \multirow[t]{2}{*}{ TAN-13A } & Time to peak (yr) & 0.00 & 0.00 & 0.00 \\
\hline & Peak concentration $(\mathrm{pCi} / \mathrm{L})$ & 0.00 & 0.00 & 0.00 \\
\hline \multirow{2}{*}{$\begin{array}{l}\text { Below center of TAN/TSF STF } \\
\text { Disposal pond }\end{array}$} & Time to peak, yrs & 0.00 & 58 & 140 \\
\hline & Peak concentration $(\mathrm{pCi} / \mathrm{L})$ & 0.00 & $1.56 \mathrm{E}-02$ & $1.55 \mathrm{E}-02$ \\
\hline Idaho National Laboratory Site & $\begin{array}{l}\text { Maximum contaminant } \\
\text { level }(\mathrm{pCi} / \mathrm{L})\end{array}$ & $119^{\mathrm{a}}$ & $100^{\mathrm{b}}$ & 8 \\
\hline Idaho National Laboratory Site & $\begin{array}{l}\text { Contract required detection } \\
\text { limits }(\mathrm{pCi} / \mathrm{L})\end{array}$ & $30^{\mathrm{c}}$ & $30^{\mathrm{c}}$ & $1^{\mathrm{c}}$ \\
\hline \multicolumn{5}{|c|}{$\begin{array}{l}\text { a. The MCL for Cs-137 is derived from a limit of } 4 \mathrm{mrem} / \mathrm{yr} \text { cumulative dose equivalent to the public, assuming a lifetime } \\
\text { intake of } 2 \mathrm{~L} / \text { day of water. }\end{array}$} \\
\hline \multicolumn{5}{|c|}{ b. 40 CFR 141, Primary Drinking Water Standards. } \\
\hline \multicolumn{5}{|c|}{ c. Quality Assurance Project Plan for Waste Area Groups 1, 2, 3, 4, 5, 6, 7, 10 and Inactive Sites (DOE-ID 2006d). } \\
\hline
\end{tabular}

As shown in Table 3-1, groundwater flows 115 degrees to the east and south, in the direction of CERCLA OU 1-07B, which encompasses the TSF injection well and its plume. The injection well is approximately $250 \mathrm{ft}$ east of the disposal pond. Figure 3-1 shows the trichloroethylene plume from the TSF-05 injection well extending in an arc to the south as far as the Water Reactor Research Test Facility, approximately 2 miles away. This map does not take into account data from the disposal pond, but it does indicate the area in which contamination from the disposal pond would migrate. The actual proportion of contamination contributed by the disposal pond to the injection well plume area is difficult, if not impossible, to determine. In addition, as discussed in Section 3.1, some residual contamination in the process/sewage drain lines may result in a small increase in contamination in the disposal pond if effluent continues to be discharged to the disposal pond; however, the risk of new inadvertent contamination is low.

Cs-137, Sr-90, and tritium are contaminants of concern (COCs) for the injection well and its plume. The Remedial Design/Remedial Action Scope of Work Test Area North Final Groundwater Remediation Operable Unit 1-07B (DOE-ID 2001c) summarizes the maximum concentrations for tritium, Sr-90, and Cs-137 in the vicinity of the injection well (hot spot and medial zone). Tritium is below the MCL. The levels for Sr-90 and Cs-137 are both significantly above MCLs but are close to the DOE Order 5400.5 Derived Concentration Guides (DCGs) (a higher threshold than the MCLs). The highest concentration for Cs-137 $(2.15 \mathrm{E}-06 \mu \mathrm{Ci} / \mathrm{mL}$ ) is below the Cs-137 DCG of 3.E-06 $\mu \mathrm{Ci} / \mathrm{mL}$ (DOE-ID 2001 , page 6). The highest detected Sr-90 concentration $(1.88 \mathrm{E}-06 \mu \mathrm{Ci} / \mathrm{mL})$ is just above the Sr-90 DCG of $1 . \mathrm{E}-06 \mu \mathrm{Ci} / \mathrm{mL}$. 


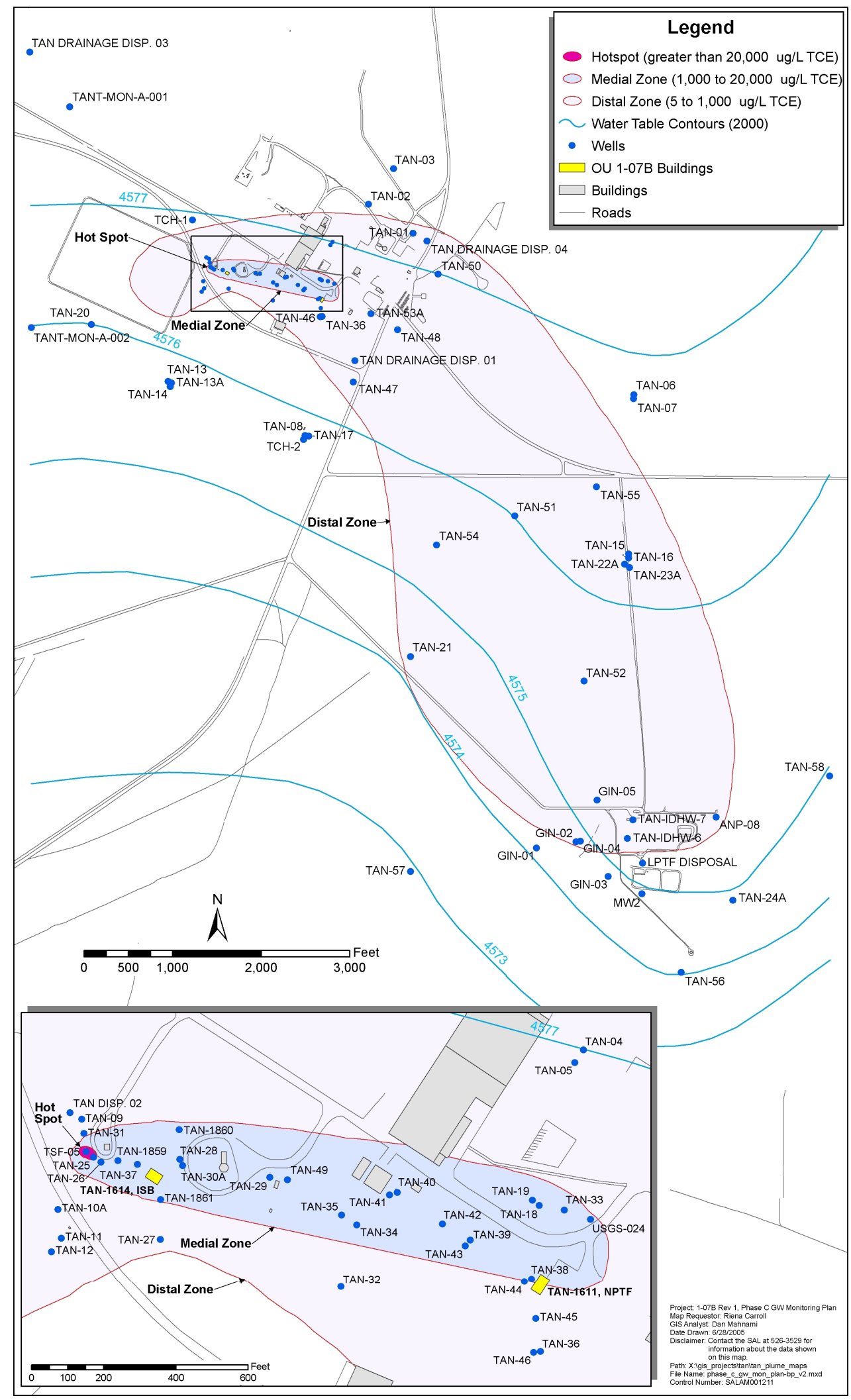

Figure 3-1. Test Area North/Technical Support Facility injection well/ trichloroethylene plume location (DOE/ID 2001b). 
In the distal zone of the plume, radiological concentrations are lower than in the hot spot and medial zone. For example, sample results from monitoring Well TAN-10A, about $180 \mathrm{ft}$ south of the injection well and about $200 \mathrm{ft}$ east of the disposal pond, are tabulated in Table 3-4. Contamination in this area, being farther from the injection well itself and its immediate plume, is more likely to be influenced by additional contamination from the disposal pond. Data from the past 17 years indicate that samples analyzed for Cs-137, Sr-90, or tritium have not had results above DOE Order 5400.5 DCGs. Thus, it can be assumed that contaminants leaving the disposal pond area are below the threshold of concern established in the DOE order. Moreover, the concentrations show a generally decreasing trend over time. The sample results are given in both $\mathrm{pCi} / \mathrm{L}$ and $\mu \mathrm{Ci} / \mathrm{mL}$ in Table 3-4 for ease of comparison with the DOE order DCG values.

The institutional controls required by the TSF-07 Disposal Pond ROD (DOE-ID 1999) do not identify perched water or groundwater monitoring as a requirement, most likely because of the low levels of radiological contamination detected in the perched water and the disposal pond sediments. However, the ROD for OU 1-07B (DOE-ID 2001b) requires groundwater monitoring because Cs-137, Sr-90, and tritium are identified as COCs. Levels of these COCs must be monitored to confirm that remedial action objectives for the COCs are met within the remedial timeframe of 100 years.

The OU 1-07B ROD identified monitored natural attenuation for reducing contamination in the distal zone (i.e., isotope half-life and dispersion [the half-life of Cs-137 is approximately 30 years, the half-life of Sr-90 is approximately 28 years, and the half-life of tritium is approximately 12 years]). The OU 1-07B ROD also notes that because institutional controls "would be in place, there would be no change in risk to human health or ecological receptors. ... Continued groundwater monitoring and computer modeling would be used to track the plume boundary; the institutional controls area would be modified as required to maintain a conservative buffer zone around the contaminant plume area" (DOE-ID 2001b, page 5).

In summary, given:

- The half-lives of the radiological contaminants

- That current concentrations of radiological contaminants are below DOE Order 5400.5 guidelines

- $\quad$ That results from the model that show that although radiological contaminants are predicted to reach groundwater, the activities are far below regulatory limits, and radiological contaminants will not migrate from the disposal pond due to added effluent for at least 58 years

- $\quad$ The low risk of additional contamination due to decreasing activities at TAN/TSF activities

- $\quad$ The direction in which the groundwater flows (toward a groundwater plume that is currently being treated)

- $\quad$ The remediation actions required for the TSF-05 Injection Well and its groundwater plume

- That institutional controls for the disposal pond area, as well as the downgradient plume are in place

ICP concludes there is no impact from effluent releases that would justify eliminating the effluent or changing its disposal location. Therefore, the risk associated with the spread of radionuclide contamination due to continued wastewater release to the disposal pond is acceptable. The conclusion from the 2-year review remains unchanged. 
Table 3-4. Sample results from groundwater monitoring Well TAN-10A.

\begin{tabular}{|c|c|c|c|c|c|c|}
\hline \multirow[b]{2}{*}{ Date $^{a, b, c}$} & \multicolumn{2}{|c|}{$\begin{array}{c}\text { Cesium }-137 \\
\mathrm{DCG}=3.0 \mathrm{E}-06 \mu \mathrm{Ci} / \mathrm{mL}\end{array}$} & \multicolumn{2}{|c|}{$\begin{array}{c}\text { Strontium-90 } \\
\mathrm{DCG}=1.0 \mathrm{E}-06 \mu \mathrm{Ci} / \mathrm{mL}\end{array}$} & \multicolumn{2}{|c|}{$\begin{array}{c}\text { Tritium } \\
\mathrm{DCG}=2.0 \mathrm{E}-03 \mu \mathrm{Ci} / \mathrm{mL}\end{array}$} \\
\hline & $\mathrm{pCi} / \mathrm{L}$ & $\mu \mathrm{Ci} / \mathrm{mL}$ & $\mathrm{pCi} / \mathrm{L}$ & $\mu \mathrm{Ci} / \mathrm{mL}$ & $\mathrm{pCi} / \mathrm{L}$ & $\mu \mathrm{Ci} / \mathrm{mL}$ \\
\hline $12 / 89$ & $<30$ & $0.030 \mathrm{E}-06$ & 76 & $0.076 \mathrm{E}-06$ & 2,800 & $0.0028 \mathrm{E}-03$ \\
\hline $1 / 90$ & $<30$ & $0.030 \mathrm{E}-06$ & 75 & $0.075 \mathrm{E}-06$ & 2,800 & $0.0028 \mathrm{E}-03$ \\
\hline $10 / 90$ & $<30$ & $0.030 \mathrm{E}-06$ & 470 & $0.470 \mathrm{E}-06$ & 3,600 & $0.0036 \mathrm{E}-03$ \\
\hline $11 / 91$ & $<30$ & $0.030 \mathrm{E}-06$ & 470 & $0.470 \mathrm{E}-06$ & 3,600 & $0.0036 \mathrm{E}-03$ \\
\hline 6/92 & $<30$ & $0.030 \mathrm{E}-06$ & 150 & $0.150 \mathrm{E}-06$ & 2,500 & $0.0025 \mathrm{E}-03$ \\
\hline $10 / 92$ & $<30$ & $0.030 \mathrm{E}-06$ & 181 & $0.181 \mathrm{E}-06$ & 1,940 & $0.0019 \mathrm{E}-03$ \\
\hline $3 / 94$ & $<30$ & $0.030 \mathrm{E}-06$ & 166 & $0.166 \mathrm{E}-06$ & 1,500 & $0.0015 \mathrm{E}-03$ \\
\hline $6 / 94$ & $<30$ & $0.030 \mathrm{E}-06$ & 153 & $0.153 \mathrm{E}-06$ & 1,600 & $0.0016 \mathrm{E}-03$ \\
\hline $10 / 94$ & $<30$ & $0.030 \mathrm{E}-06$ & 153 & $0.153 \mathrm{E}-06$ & 2,100 & $0.0021 \mathrm{E}-03$ \\
\hline $11 / 94$ & $<30$ & $0.030 \mathrm{E}-06$ & 148 & $0.148 \mathrm{E}-06$ & 2,100 & $0.0021 \mathrm{E}-03$ \\
\hline $10 / 95$ & $<30$ & $0.030 \mathrm{E}-06$ & 131 & $0.131 \mathrm{E}-06$ & 860 & $0.0009 \mathrm{E}-03$ \\
\hline $2 / 96$ & - & - & 117 & $0.117 \mathrm{E}-06$ & - & - \\
\hline $3 / 96$ & - & - & 117 & $0.117 \mathrm{E}-06$ & - & - \\
\hline $8 / 96$ & $<2$ & $0.002 \mathrm{E}-06$ & 116 & $0.116 \mathrm{E}-06$ & 1,020 & $0.0028 \mathrm{E}-03$ \\
\hline 9/96 & $<5$ & $0.005 \mathrm{E}-06$ & 117 & $0.117 \mathrm{E}-06$ & 1,020 & $0.0028 \mathrm{E}-03$ \\
\hline $8 / 97$ & & & 11 & $0.011 \mathrm{E}-06$ & 789 & $0.0008 \mathrm{E}-03$ \\
\hline 6/99 & $<14$ & $0.014 \mathrm{E}-06$ & 91 & 0.091E-06 & 781 & $0.0008 \mathrm{E}-03$ \\
\hline $2 / 00$ & - & - & 96 & $0.096 \mathrm{E}-06$ & 605 & $0.0006 \mathrm{E}-03$ \\
\hline $7 / 00$ & - & - & 73 & $0.073 \mathrm{E}-06$ & 681 & $0.0008 \mathrm{E}-03$ \\
\hline $11 / 00$ & 0 & 0 & 124 & $0.124 \mathrm{E}-06$ & 533 & $0.0005 \mathrm{E}-03$ \\
\hline $2 / 01$ & 0 & 0 & 95 & $0.095 \mathrm{E}-06$ & 495 & $0.0005 \mathrm{E}-03$ \\
\hline $6 / 01$ & - & - & - & - & 628 & $0.0006 \mathrm{E}-03$ \\
\hline $11 / 01$ & - & - & - & - & 478 & $0.0005 \mathrm{E}-03$ \\
\hline $2 / 02$ & - & - & - & - & 514 & $0.0005 \mathrm{E}-03$ \\
\hline $4 / 03^{c}$ & 0.489 & 4.89E-07 & 93.8 & $9.38 \mathrm{E}-05$ & 278 & $2.78 \mathrm{E}-04$ \\
\hline $10 / 03$ & 1.89 & $1.89 \mathrm{E}-06$ & 108 & $1.08 \mathrm{E}-04$ & 372 & $3.72 \mathrm{E}-04$ \\
\hline $4 / 04$ & 0.725 & $7.25 \mathrm{E}-07$ & 92.4 & $9.24 \mathrm{E}-05$ & 245 & $2.45 \mathrm{E}-04$ \\
\hline $7 / 04$ & 1.42 & $1.42 \mathrm{E}-06$ & 91.4 & $9.14 \mathrm{E}-05$ & 321 & $3.21 \mathrm{E}-04$ \\
\hline $10 / 04$ & 2.62 & $2.62 \mathrm{E}-06$ & 81.7 & $8.17 \mathrm{E}-05$ & 209 & $2.09 \mathrm{E}-04$ \\
\hline $4 / 05$ & -0.7 & $-7.00 \mathrm{E}-07$ & 90.6 & $9.06 \mathrm{E}-05$ & 243 & $2.43 \mathrm{E}-04$ \\
\hline
\end{tabular}


Table 3-4. (continued).

\begin{tabular}{|c|c|c|c|c|c|c|}
\hline \multirow[b]{2}{*}{ Date $^{\mathrm{a}, \mathrm{b}, \mathrm{c}}$} & \multicolumn{2}{|c|}{$\begin{array}{c}\text { Cesium- } 137 \\
\mathrm{DCG}=3.0 \mathrm{E}-06 \mu \mathrm{Ci} / \mathrm{mL} \\
\end{array}$} & \multicolumn{2}{|c|}{$\begin{array}{c}\text { Strontium-90 } \\
\mathrm{DCG}=1.0 \mathrm{E}-06 \mu \mathrm{Ci} / \mathrm{mL}\end{array}$} & \multicolumn{2}{|c|}{$\begin{array}{c}\text { Tritium } \\
\mathrm{DCG}=2.0 \mathrm{E}-03 \mu \mathrm{Ci} / \mathrm{mL}\end{array}$} \\
\hline & $\mathrm{pCi} / \mathrm{L}$ & $\mu \mathrm{Ci} / \mathrm{mL}$ & $\mathrm{pCi} / \mathrm{L}$ & $\mu \mathrm{Ci} / \mathrm{mL}$ & $\mathrm{pCi} / \mathrm{L}$ & $\mu \mathrm{Ci} / \mathrm{mL}$ \\
\hline $10 / 05$ & 8.7 & 8.7E-06 & 83 & $8.3 \mathrm{E}-05$ & 570 & $5.70 \mathrm{E}-04$ \\
\hline $4 / 06$ & 5.98 & 5.98E-06 & 127 & $1.27 \mathrm{E}-04$ & 79.3 & 7.93E-05 \\
\hline $10 / 06$ & 2.05 & $2.05 \mathrm{E}-06$ & 94.8 & $9.48 \mathrm{E}-05$ & 241 & $2.41 \mathrm{E}-04$ \\
\hline \multicolumn{7}{|c|}{ a. Sample data for 12/89 through 6/99 based on data tables in INEEL 1999 and INEEL $2001 \mathrm{in} \mathrm{pCi/L.}$} \\
\hline \multicolumn{7}{|c|}{$\begin{array}{l}\text { b. Sample data for } 2 / 00 \text { to } 2 / 02 \text { based on communication from Lee Nelson, Environmental Restoration Closure Project for } \\
\text { WAG } 1 \text { in } \mathrm{pCi} / \mathrm{L} \text {. }\end{array}$} \\
\hline
\end{tabular}




\section{CONCLUSION}

This ICS continues to document that continued discharges are acceptable, given the low risk resulting from limited contaminant migration, effluent wastewater controls currently in place, and monitoring of those controls (as required by the RODs for both the disposal pond area and the downgradient injection well and its plume). Discharge of current amounts of effluent are not appreciably increasing risk or the amount of contamination, and such discharges will, in all likelihood, be reduced and eliminated by 2012, if not sooner. Expenditure of funds for Alternatives 1 and 2 are not justified, given current operational and CERCLA (42 USC $§ 9601)$ controls. As discharges are eliminated, the disposal pond will be in full compliance with DOE Order 5400.5 requirements.

In accordance with DOE Order 5400.5, this ICS must be reviewed every 2 years. This review will be based on:

- $\quad$ Required annual updates to the Best Available Technology Status Report

- $\quad$ Required annual institutional controls plan assessment for OU 1-10

- Groundwater monitoring of the TAN wells and periodic performance reports, as required by the OU 1-07B ROD.

- $\quad$ Required review of OU 1-10 ROD "Limited Action" remedy to be "conducted no less than every 5 years until it is determined by DOE to be unnecessary." NOTE: Last review conducted in fall 2005.

These documents, along with monitoring the status of TAN/TSF DD\&D process, provide a basis to assess this ICS on a 2-year basis and modify it as warranted by any change in conditions or regulatory drivers.

Given the cost of Alternatives 1 and 2, weighed against either alternative's insignificant increase in protection of workers, the public, and the environment, ICP recommends Alternative 3, no action other than continued implementation of existing ROD controls and continued DD\&D efforts at TAN. For purposes of the 2-year review, ICP's recommendation remains unchanged. 


\section{REFERENCES}

10 CFR 20, "Standards for Protection Against Radiation," Code of Federal Regulations, Office of the Federal Register.

40 CFR 141, "National Primary Drinking Water Regulations," Code of Federal Regulations, Office of the Federal Register.

42 USC § 4321 et seq., 1970, "National Environmental Policy Act of 1969,” United States Code, January $1,1970$.

42 USC $§ 9601$ et seq., 1980, "Comprehensive Environmental Response, Compensation and Liability Act of 1980," United States Code, December 11, 1980.

DOE-ID, 1994, Track 2 Sites: Guidance for Assessing Low Probability Hazard Sites at the INEL, DOE/ID-10389, January 1994, Rev. 6.

DOE-ID, 1996, Idaho National Engineering Laboratory Comprehensive Facility and Land Use Plan, DOE/ID-10514, Rev. 0, U.S. Department of Energy Idaho Operations Office, March 1996. (NOTE: This version contains OUO information. It is available internally at: http://meris.inel.gov. An unclassified version, DOE/ID-10514-97, is available at: http://cflup.inel.gov for external access.)

DOE-ID, 1997, Comprehensive Remedial Investigation/Feasibility Study for the Test Area North Operable Unit 1-10 at the INEL, DOE/ID-10557, Rev. 0, November 1997.

DOE-ID, 1999, Final Record of Decision for Test Area North, DOE/ID-10682, Rev. 0, October 1999, U.S. Department of Energy; Idaho National Engineering and Environmental Laboratory, U.S. Environmental Protection Agency; Idaho Department of Health and Welfare, Division of Environmental Quality.

DOE-ID, 2001a, Operations and Maintenance Plan for Test Area North, Operable Unit 1-10, DOE/ID-10711, Rev. 1, U.S. Department of Energy Idaho Operations Office, November 2001.

DOE-ID, 2001b, Record of Decision Amendment for the Technical Support Facility Injection Well (TSF-05) and Surrounding Groundwater Contamination (TSF-023) and Miscellaneous No Action Sites, Final Remedial Action, DOE/ID-10139, August 2001.

DOE-ID, 2001c, Remedial Design/Remedial Action Scope of Work Test Area North Final Groundwater Remediation Operable Unit 1-07B, DOE/ID-10905, Rev. 1, March 2001.

DOE-ID, 2002, Comprehensive Remedial Design/Remedial Action Work Plan for Test Area North, Waste Area Group 1, Operable Unit 1-10, Group 2 Sites, DOE/ID-10875, Rev. 1, U.S. Department of Energy Idaho Operations Office, March 2002.

DOE-ID, 2004, INEEL Sitewide Operations and Maintenance Plan for CERCLA Response Actions, DOE/NE-ID-11159, Rev. 0, U.S. Department of Energy Idaho Operations Office, September 2004. 
DOE-ID, 2006a, Remedial Action Report for OU 1-10, Group 1 and Group 3 Sites, at Test Area North, WAG 1 (DRAFT), DOE/ID-11262, January 2006.

DOE-ID, 2006b, INL Sitewide Institutional Controls Plan, DOE/ID-11042, Rev. 3, July 2006.

DOE-ID, 2006c, Idaho National Laboratory (INL) Sitewide Institutional Controls Annual Report - FY 2006 (FY-06), DOE/ID-11289, Rev. 0, August 2006.

DOE-ID, 2006d, Quality Assurance Project Plan for Waste Area Groups 1,2,3,4,5, 6, 7,10 and Inactive Sites, DOE/ID-10587, Rev. 9, July 2006.

DOE Order 5400.5, Chg 2, January 7,1993, "Radiation Protection of the Public and the Environment," U.S. Department of Energy, Washington, D.C.

ICP, 2003, Clean/Clsoe TAN - 2004 DWP, ICP/EXT-03-00028.

ICP, 2004, 2004 Status Update for Implementing Best Available Technical Technology per DOE Order 5400.5, ICP/EXT-04-00535.

ICP, 2005, 2005 Radiological Monitoring Results Associated with the Test Area North/Technical Support Facility Sewage Treatment Facility, ICP/EXT-05-01110.

ICP, 2006, 2006 Radiological Monitoring Results Associated with the Test Area North/Technical Support Facility Sewage Treatment Facility, RPT-289.

INEEL, 1999, Fiscal Year 1999 Groundwater Monitoring Annual Report Test Area North Operable Unit 1-07B, INEEL/EXT-99-01255, Rev. 0, April 2000.

INEEL, 2000a, Wastewater Land Application Permit Renewal Application for the Test Area North/Technical Support Facility Sewage Treatment Facility, INEEL/EXT-2000-01049, October 2000.

INEEL, 2000b, Institutional Control Plan for the Test Area North Waste Area Group 1, INEEL/EXT-2000-00917, Rev. 0, Idaho National Engineering and Environmental Laboratory, September 2000.

INEEL, 2001, Fiscal Year 2000 Groundwater Monitoring Annual Report Test Area North Operable Unit 1-07B, INEEL/EXT-01-00767, Rev. 0, September 2001.

INEEL, 2002, Phase C Groundwater Monitoring Plan, Test Area North Operable Unit 1-07B, INEEL/EXT-99-00021, Rev. 1, April 2002.

INEL, 1995, Remedial Action Report Test Area North Groundwater Interim Action Operable Unit 1-07 A" Rev. 3 (Revision 3 of this document was issued as Final Progress Report for Batches 1-31 Test Area North Groundwater Interim Action Operable Unit 1-07A), Document No. 1.07 A.2.1.209.01). 
Johnston, James, Idaho Department of Environmental Quality, to Richard B. Provencher, U.S. Department of Energy Idaho Operations Office, and D. Brent Rankin, Idaho Cleanup Project, October 21, 2005, "Minor Modification "B," Idaho National Laboratory, Test Area North/Technical Support Facility, Sewage Treatment Facility, Wastewater Land Application Permit LA-000153-02," CCN 301354, PER-37.

Kaminiski, J. F., K. N. Keck, A. L. Schafer-Perini, C. F. Hersley, R. P. Smith, G. J. Stormberg, A. H. Wylie, 1994, Remedial Investigation Final Report with Addenda for the Test Area North Groundwater Operable Unit at the Idaho National Engineering Laboratory, EGG-ER-10643, Rev. 0, Idaho National Engineering Laboratory, January 1994.

Medina, S. M., 1993, Evaluation of Historical and Analytical Data on the TAN TSF-07 Disposal Pond, EGG-ERD-10422, July 1993, Idaho National Engineering Laboratory.

Rood, A. S., 2003, GWSCREEN: A Semi-Analytical Model for Assessment of the Groundwater Pathway from Surface or Buried Contamination; Theory and User's Manual Version 2.5, INEEL/EXT-98-00750, Rev. 1b, Idaho National Engineering and Environmental Laboratory.

Sorenson, K. S., 2000, Intrinsic and Enhanced In Situ Biodegradation of Trichloroethene in a Deep, Fractured Basalt Aquifer, PhD Dissertation, University of Idaho Department of Civil Engineering, May 2000. 


\section{Appendix A}

\section{TSF-07 Background from the Remedial Investigation/Feasibility Study}


A-2 


\section{Appendix A}

\section{TSF-07 Background form the Remedial Investigation/Feasibility Study}

Source: DOE/ID-10557, Comprehensive Remedial Investigation/Feasibility Study for the Test Area North Operable Unit 1-10 at the Idaho National Engineering and Environmental Laboratory, Rev. 0, November 1997.

NOTE: The above report has not changed from the original document, other than to revise the treatment for the V-tanks, which does not impact this report. 
The area of contamination at the site extends from the surface to the soil/basalt interface and includes the area where the tanks and concrete cradles are located, as well as the surrounding soils in an overall area of 30.5 by $21.3 \mathrm{~m}$ ( $100 \mathrm{by} 70 \mathrm{ft})$. This is based on the results of the geophysical survey and the borings drilled during the 1988 DOE survey and the Track 2 investigation. Radionuclides (Cs-137 and Co-60) are the COPCs detected in the subsurface soils about ambient levels. Tributyl pbosphate was detected; however due to its low frequency of detection, it is not considered a COPC. The assumption that the subsurface soils in the area are contaminated to the soil and basalt interface is very conservative because no sampling and analysis results are available below $5.2 \mathrm{~m}(17 \mathrm{ft})$ bgs. The estimated area of contamination is also conservative because the estimate is based on four soil borings that were drilled during the 1988 DOE survey. Although benzene and chloroethane were detected during the Track 2 sandpoint sampling, the Track 2 concluded these should not be considered COPCs because they were not detected in any of the numerous soil samples collected at the site. The results may, however, indicate potential release or spillage from the tanks to the protective cradle.

On the basis of historical information on site users. the 1993 Track 2 investigation and the 1995 OU 10-06 removal action, all of the surface soils 0 to $0.8 \mathrm{~m} \mathrm{(0} \mathrm{to} 2.5 \mathrm{ft})$ within the chain-link fence at the PM-2A site area assumed to be contaminated as well as the soil outside the fence extending to Firehold Road. Results of the 1996 soil samples collected during the OU 10-06 removal action the residual nature and extent of the contamination remaining at the TSF-26 site, and risks presented by that contamination are evaluated under this RI/BRA. The TSF-26 area was subject to removal. at which time it was discovered that the radiation levels exceeded the transportation limits for one load of soil. Approximately $1,700 \mathrm{yd}^{3}$ of soil were removed; however, the samples of stockpiled soil at the site were well above the 10-06 PRG of $16.7 \mathrm{pCi} / \mathrm{g}$ for Cs-137. The assumptions for the remaining contamination as well as the source-term estimates for TSF-26 are shown in Figure 4-31.

The COPCs at TSF-26 and TSF PM-2A, based on the contaminant screening process detailed in Section 6 and Table B-21, are shown in Table 4-16.

\subsubsection{OU 1-06: TSF-07, Disposal Pond}

4.1.10.1 Site Summary. TSF-07 is an unlined disposal pond located southwest of the TSF, as shown in figure 4-32. The TSF-07 site encompasses a total area of approximately 35 acres, of which 5 acres in the northeast corner and on the eastern edge are believed to be contaminated with radionuclides and metals. The remaining 30 acres have never received wastewater and are not contaminated based on available screening data. The TSF- 07 pond is unlined and surrounded by a $1.5-\mathrm{m}(5-\mathrm{ft})$ berm. The active portion of the pond consists of a 1.5-acre main pond along the eastern edge. The overflow pond is a 1 -acre pond along the northeast edge of the berm and has rarely been used. The TSF-07 disposal pond replaced the TSF-05 injection well and began receiving wastewater in September 1972. No radioactivity above background values was detected in a field survey of the western half of the TSF-07 pond performed in 1993. These results are interpreted to indicate that this end of the pond has not been used and that contaminants are not migrating horizontally from the contaminated eastern end of the pond.

The pond received wastewater from a variety of sources including sanitary waste discharges, lowlevel radioactive waste, cold process water, and treated sewage effluent originating from TAN service buildings and processes and, more recently, a one-time release of 40,000 gal of treated wastewater from TAN-726. Borated water was also transported from the LOFT facility and poured into a manhole leading into the pond when LOFT was operational. The wastewater was piped to and mixed in a common sump (TAN-655) and subsequently pumped to a concrete inlet basin in the northeast corner of the TSF-07 disposal pond. Wastewater was discharged to TSF-07 via a drainage ditch. The sediment thickness in the pond has been estimated to range from $7.5 \mathrm{~m}(24.5 \mathrm{ft})$ at well No. TAN-9, to $19.5 \mathrm{~m}(64 \mathrm{ft})$ at well No. TSFAG-07, with an average thickness of $13.7 \mathrm{~m} \mathrm{(45} \mathrm{ft).}$ 


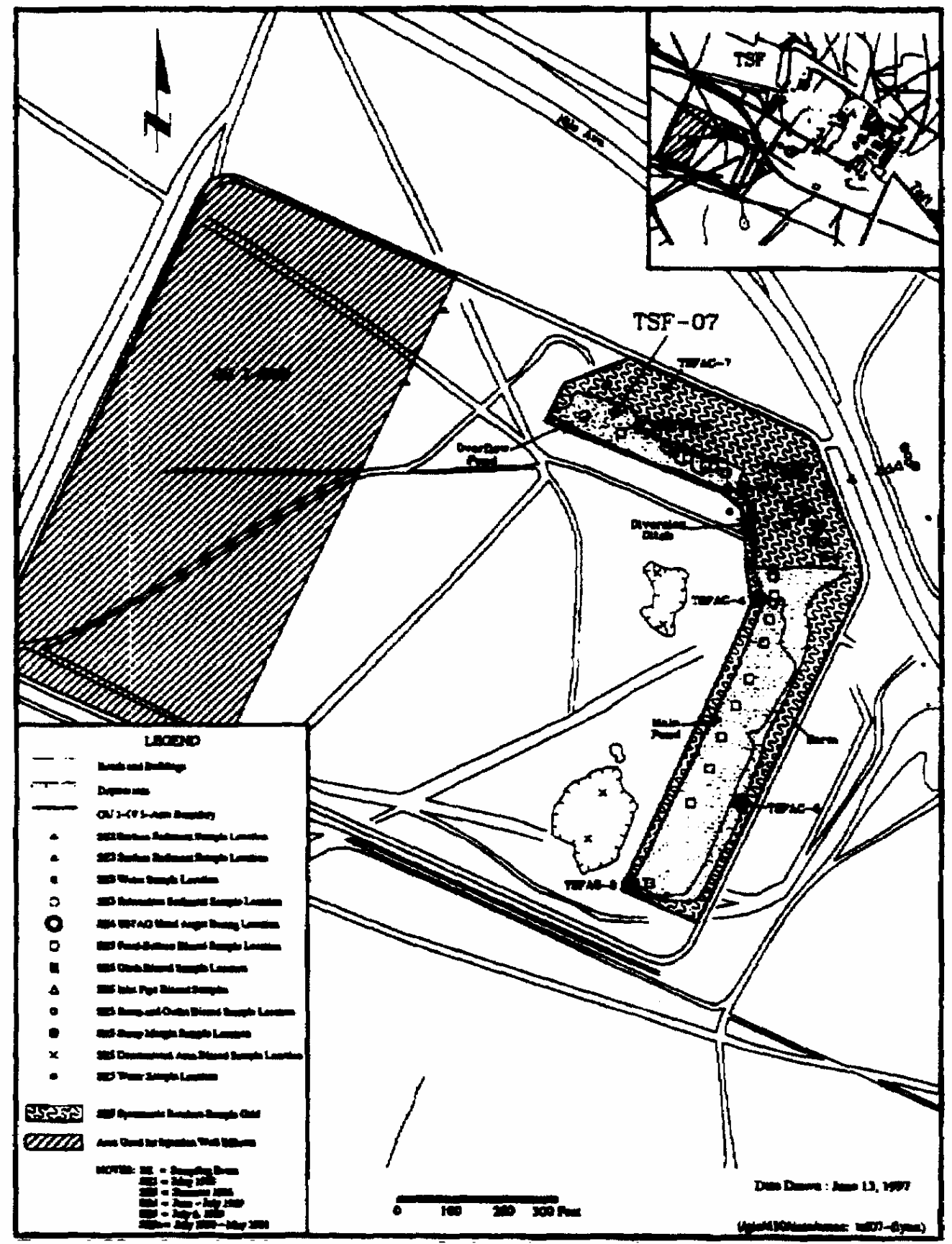

Figure 4-32. OU 1-06; TSF-07, TSF Disposal Pond, showing sampling locations for sampling events.

4.1.10.2 Previous Investigations. Results from samples of sludge in the common sump indicated the suspected contaminants for the TSF-07 are metals, SVOCs, VOCs, PCBs, Co-60, and Cs-137. Surface water, sediments, subsurface soil, and perched water associated with the TSF-07 disposal pond have been sampled from 1982 to 1991 (see Figure 4-33). The data for these events were summarized in the Track 1 decision document for TSF-07 and were considered to adequately characterize the occurrence of suspected contaminants given the common sump sample results and process knowledge associated with the wastewater disposed to TSF-07. Samples collected in 1988 were analyzed for the analytes found in 
40 Code of Federal Regulations (CFR) Part 264, Appendix IX. Surface water and sediment samples collected in 1988 by the DOE environmental survey were analyzed for metals; VOCs; and select alpha-, beta-,and gamma-emitting radionuclides. The 1989 subsurface investigation characterized sediment, subsurface soil, and surface water. Perched water, attributed solely to the discharge of wastewater to TSF-07, was characterized in 1991.

Approximately 129 samples have been collected during the course of these sampling events. The following paragraphs discuss the sample results for inorganic, organic, and radionuclide contamination with respect to sediment and subsurface soil. Surface water and perched water results are also discussed in the following paragraphs of this section.

The combined results of the previous investigations indicate that metals contamination has been detected in the pond sediment and subsurface soil and is assumed to exist up to a depth of $3.4 \mathrm{~m}(11 \mathrm{ft})$. Beryllium, chromium, mercury, and thallium are the most frequently ( $>34 \%$ of the sample) detected metals. Surface water data indicated the presence of beryllium, silver, and vanadium. Arsenic, antimony, thallium, and beryllium were detected in perched water samples; however, maximum concentrations were within an order of magnitude of Snake River Plain Aquifer background (when available) and were not detected consistently in the perched water samples (Medina 1993). The organic contaminants detected in soil samples at TSF-07 include toluene $(0.07 \mathrm{mg} / \mathrm{kg})$, aroclor-1254 $(0.67 \mathrm{mg} / \mathrm{kg})$, and aroclor-1260 $(1.7$ $\mathrm{mg} / \mathrm{kg})$. These contaminants were detected at depths of $0.6 \mathrm{~m}(2 \mathrm{ft})$. Acetone $(0.24 \mathrm{mg} / \mathrm{kg})$ and methylene chloride were detected at $7.9 \mathrm{~m}(26 \mathrm{ft})$ and $6.4 \mathrm{~m}(21 \mathrm{ft}) \mathrm{bgs}$, respectively. All other detected organic contaminants were observed from 0 to $0.6 \mathrm{~m}(0$ to $2 \mathrm{ft}) \mathrm{bgs}$. Acetone was also detected in the surface water at a concentration of $11.0 \mu \mathrm{g} / \mathrm{L}$. Organic contaminants were not detected in the perched water (Medina 1993).

As concluded in the evaluation of historical and analytical data on the TAN TSF-07 Disposal Pond (Medina 1993), Co-60, Cs-137, Cs-134, strontium (total), Am-241, Eu-155, and tritium were detected in the pond sediments and shallow subsurface soils at the site. Additionally, Co-60 and Cs-137 were detected in the subsurface soil from 3 to $3.4 \mathrm{~m}$ (10 to $11 \mathrm{ft})$ bgs. Surface water sample results indicated the presence of Am-241, Co-60, Cs-137, strontium (total), and tritium. Sr-90 has been detected in the perched water with concentrations ranging from 1.0 to $136 \mathrm{pCi} / \mathrm{L}$. The average Sr-90 concentration in the perched water was approximately $13 \mathrm{pCi} / \mathrm{L}$ (Medina 1993).

The perched water beneath the TSF -07 disposal pond was encounted during the 1989 subsurface investigation for the TAN-RCRA Facility Investigation. Two of the borings that intercepted the perched water zone were converted into monitoring wells, and samples of the perched water were collected from these wells. The lateral extent of the perched water zone beneath TSF-07 has not been defined; however, monitoring indicates that the thickness of the zone varies from 2.7 to $12.2 \mathrm{~m}$ (9 to $40 \mathrm{ft})$. The occurrence of the perched water found in the two borings was in the surficial sediments above the basalt at approximately 20 to $35 \mathrm{ft}$ bgs. Perched water has been found in only two of the 14 boreholes and monitoring wells drilled near the pond since 1987. The perched water is present as a direct result of pond discharges. Once use of the pond is discontinued, the perched water zone will gradually dissipate into the subsurface basalt. The pond has 2.5 acres that remain active. The pond, considered a co-located facility receives treated sewage, boiler blowdown, and process wastewater and is permitted for Land Application of Wastewater with the State.

4.1.10.3 Nature and Extent of Contamination. Based on the sampling results, an estimated 5 acres in the eastern and northeastern corner of the pond are known to be contaminated. The highest levels of contamination are found along the drainage ditch from the inlet basin in the northeast corner of 

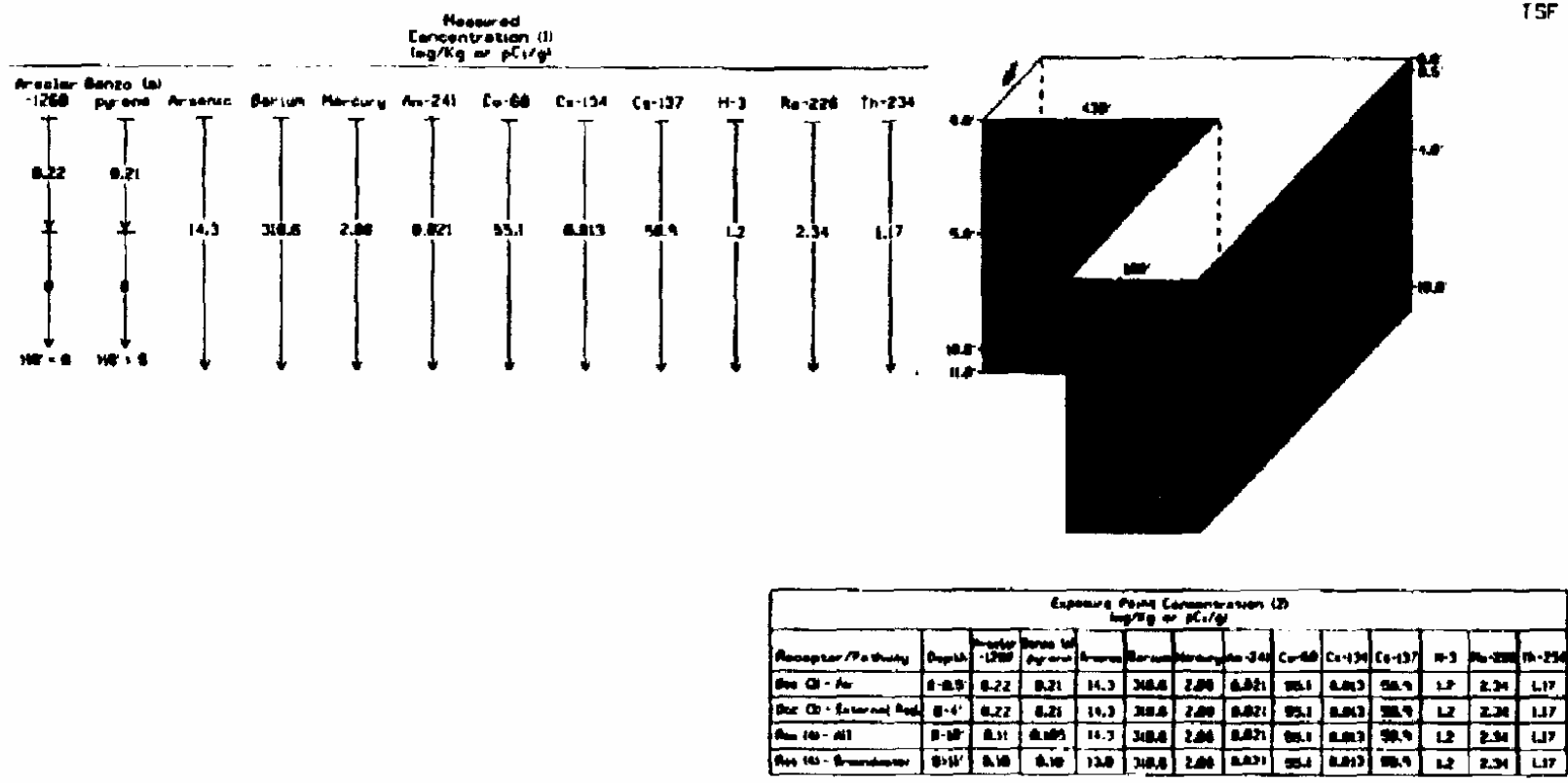

Letron.

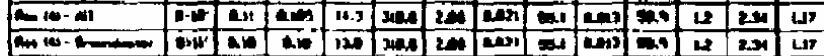

Drome of conveminotion.

Astumention

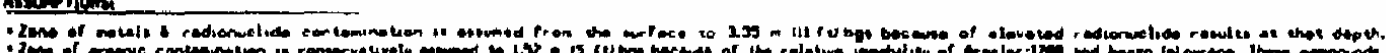

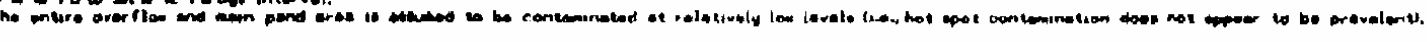

atis

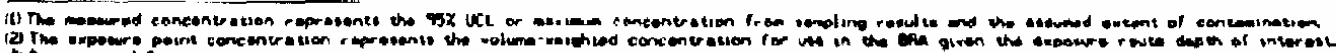

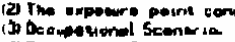

4is

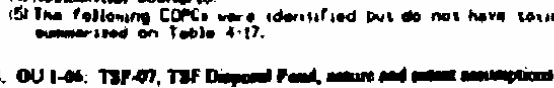

Figure 4-33. OU 1-06; TSF-07, TSF Disposal Pond, nature and extent assumptions. 
TSF-07 to the main pond along the eastern berm. The main disposal pond is approximately 192 by $30.5 \mathrm{~m}$ (630 by $100 \mathrm{ft})$, or an area of $5,856 \mathrm{~m}^{2}\left(63,000 \mathrm{ft}^{2}\right)$. The overflow pond is approximately 131 by $24 \mathrm{~m}$ $(430$ by $80 \mathrm{ft})$, or an area of $3,144 \mathrm{~m}^{2}\left(34,400 \mathrm{ft}^{2}\right)$.

A conclusion of the Track 1 report is that vertical migration of contamination has occurred as evidenced by the elevated concentrations of metals in subsurface samples. The elevated radionuclide

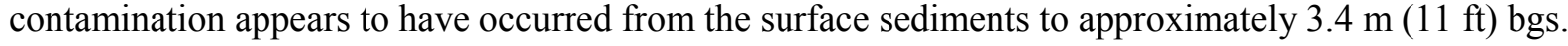
Infiltration of wastewater at the site has likely increased the mobility of the metals and radionuclide contaminants that are routinely considered immobile (i.e., Cs-137). Organic contamination is assumed to

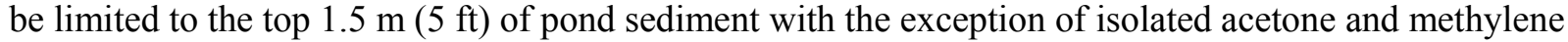
chloride detections at depth. Limited observations of contaminants in the perched water (i.e.. Sr-90) also substantiate the sorption of contaminants within the pond sediments and underlying soil. The horizontal extent of contamination is limited to the main and overflow ponds. Contamination outside the TSF-07 has not been detected by field surveys.

Additionally, n-propylbenzene, phenanthrene, propionitrile, tetrahydrofuran, sulfide, and thallium arc retained as COPCs due to the lack toxicity information. These COPCs will be discussed in the uncertainty section. Based on Medina (1993) the zone of contamination for TSF-07 is dependent on the contaminant for metals, the data indicate that contamination is likely near surface and similar to that for the radionuclides [i.e., $3.4 \mathrm{~m}(11 \mathrm{ft}) \mathrm{bgs}$ ]. Radionuclide contamination is assumed to be limited to the top $3.4 \mathrm{~m}(11 \mathrm{ft})$ of pond sediment, while organic contamination is limited to the top $1.4 \mathrm{~m}(5 \mathrm{ft})$. Figure $4-33$ shows the assumptions for the nature and extent of contamination as well as the source-term estimates for TSF-07.

The COPCs for TSF-07, based on the contamination screening detailed in Section 6 and Table B-14, are shown in Table 4-17.

\subsubsection{OU 1-06, TSF-08, Area 13B, Mercury Spill}

4.1.11.1 Site Summary. TSF-08 Area B, a mercury spill, is located near the southwest corner of TAN-607, as shown in Figure 4-34. Mercury was used extensively at TSF-08 from the late 1950s to the early 1960s. The HTRE-III, part of the ANP program, used mercury as shielding for its reactor. From about 1959 to 1987, the HTRE-III engine was moved frequently along the railroad spurs between the test area at the IET facility and the maintenance areas at TAN-607 and TAN-647. The units were stored on the track near TAN-647 from the mid-1960s to 1987. It is reported that mercury leaked from the HTRE-III engine onto the ground and railroad system every time the unit was moved and that mercury beads were found on the soil near the TAN-647 storage location in the mid-1980s. Also, a large spill of mercury [3,028 to 3,785 L (800 to 1,000 gal)] reportedly occurred near the southwest corner of TAN-607 in 1958. Mercury spills were collected in buckets or simply vacuumed up until 1978. 
Table 4-17. Summary statistics for TSF-07.

Concentuntion

(Experpecin)

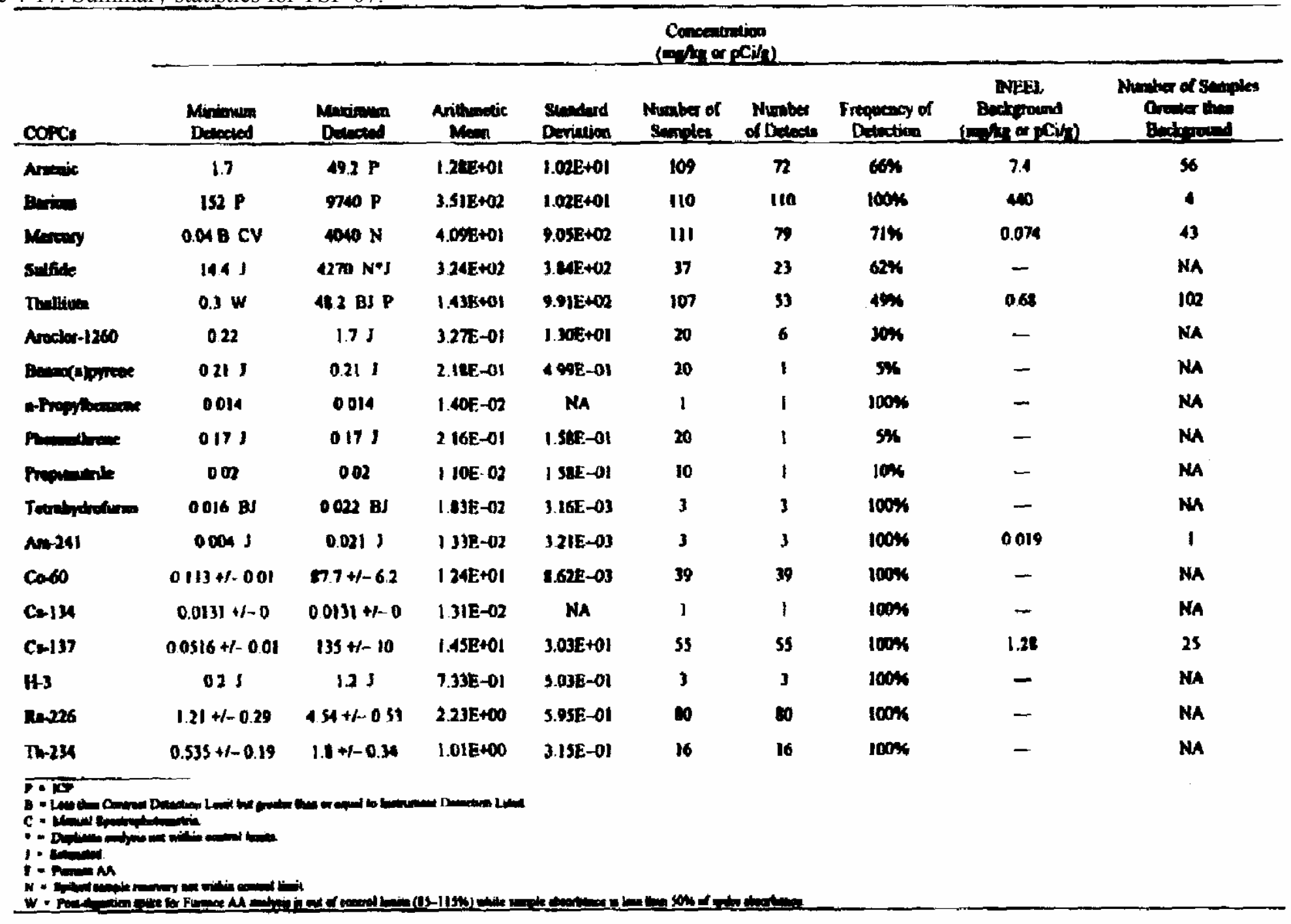


Appendix B

\section{Technical Support Facility Discharge Sources}


B-2 


\section{Technical Support Facility Discharge Sources}

Source: INEEL/EXT-2000-0149, October 2000, WLAP Renewal Application for TAN/TSF Sewage Treatment Facility 
Table 5-1. Technical Support Facility discharge sources. ${ }^{\mathrm{a}}$

\begin{tabular}{|c|c|c|}
\hline Building & Description of Use & Description of Discharge \\
\hline TAN-601, Guardhouse* & Industrial, offices & Domestic/sanitary \\
\hline TAN-603, Service* & Industrial & $\begin{array}{l}\text { Domestic/sanitary, boiler } \\
\text { blowdown, water softener } \\
\text { discharge }\end{array}$ \\
\hline $\begin{array}{l}\text { TAN-607, Assembly and Storage } \\
\text { Area* }\end{array}$ & $\begin{array}{l}\text { Industrial, demineralizer system, } \\
\text { boilers, medical services }\end{array}$ & $\begin{array}{l}\text { Domestic/sanitary, eyewash, safety } \\
\text { showers, demineralizer, boiler } \\
\text { blowdown, cooling water }\end{array}$ \\
\hline $\begin{array}{l}\text { TAN-610, Service Station- 600 } \\
\text { gallons per day to STF. BEA }\end{array}$ & Vehicle maintenance and cleaning & $\begin{array}{l}\text { Air dryer drains, steam condensate, } \\
\text { water tank discharge, emergency } \\
\text { eye wash, pump seal, pressure } \\
\text { relief, compressor condensate }\end{array}$ \\
\hline TAN-623, STP and Control Building & Industrial & Domestic/sanitary \\
\hline TAN-687, Fire Station ${ }^{\mathrm{b}}$ & Fire station & $\begin{array}{l}\text { Domestic/sanitary, HVAC } \\
\text { condensate drain }\end{array}$ \\
\hline Effluent goes to & $\begin{array}{l}\text { Yajor, } 2000 \mathrm{INEEL} \mathrm{Liqu} \\
\text { ich is pumped and disch }\end{array}$ & $\begin{array}{l}\text { Inventory. } \\
\text { AN-623. Owned by BEA. }\end{array}$ \\
\hline
\end{tabular}

*These buildings no longer discharge to the TAN/TSF sewage treatment facility disposal pond. 


\section{Appendix C}

Semi-Analytical Model for the Assessment of the Groundwater Pathway from the Leaching of Surficial and Buried Contamination and Release of Contaminants from Percolation Ponds 


$$
\text { C-2 }
$$




\section{Semi-Analytical Model for the Assessment of the Groundwater Pathway from the Leaching of Surficial and Buried Contamination and Release of Contaminants from Percolation Ponds}

Source: Rood, Arthur S., GWSCREEN Version 2.5a, Semi-analytical Model for the Assessment of the Groundwater Pathway from the Leaching of Surficial and Buried Contamination and Release of Contaminants from Percolation Ponds, September 2002. 


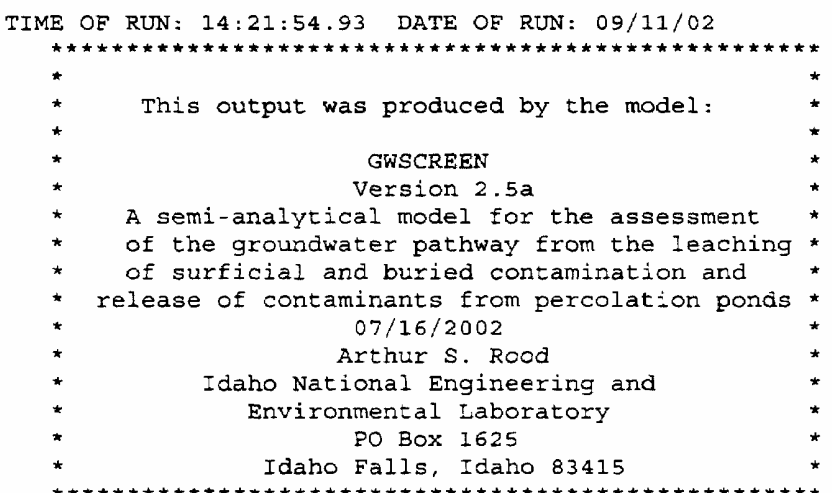

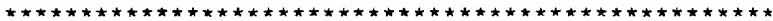

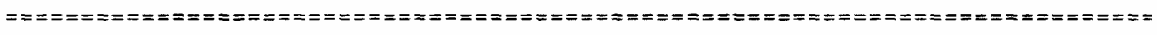
ACKNOWLEDGEMENT OF GOVERNMENT SPONSORSHIP AND

LIMITATION OF LIABILITY

This material resulted from work developed under U.S. Department of Energy, Office of Environmental Restoration and Waste Management, DOE Field office, Idaho, Contract Number DE-AC07-76ID01570.

This material is subject to a limited government license:

Copyright 1993, EG\&G Idaho Inc., Idaho National Engineering Laboratory

all rights reserved. Neither the United states nor the United states

Department of Energy, nor any of their employees, makes any warranty

expressed or implied, or assumes any legal liability or

responsibility for the accuracy, completeness, or usefulness of any

information, apparatus, product or process disclosed, or represents that

its use would not infringe on privately owned rights. Subroutines GOLDEN,

QSIMP, QGAUS, and TRAPZD are Copyright (C) 1992, Numerical Recipes

Software. Reproduced by permissior. from the book, Numerical Recipes,

Cambriage University Press.

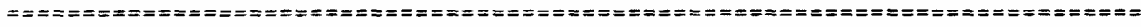

OUTPUT FILE NAME:

tsf07-2. Out

INPUT FILE NAME

tsf07-2.par

Title: Revised TSF-07 contaminant migration estimate (Card 1)

Model Run Optons

Model Run Options

IMODE Contaminant TYpe and Impacts:

ITYPE (1) Vert Avg (2) 3D Point (3) 3d Avg:

IDISP (0) Fixed Dispersivity (1-3) Spatially varying:

KFIAG (1) Max Conc (2) Conc vs Time (3) Grid Output:

IDIL (1) No dilution factor (2) Include Dilution Factor:

IMOIST Source Moisture Content Option:

IMOISTU Unsaturated Moisture Content Option:

IMODEL (1) Surface/Burried Src (2) Pond (3) Usr Def:

ISOLVE (1) Gaussian Quarature (2) Simpsons Rule: (Aquifer)

ISOLVEU (1) Gaussian Quarature (2) Simpsons Rule: (Unsat zone)

ISTART : 


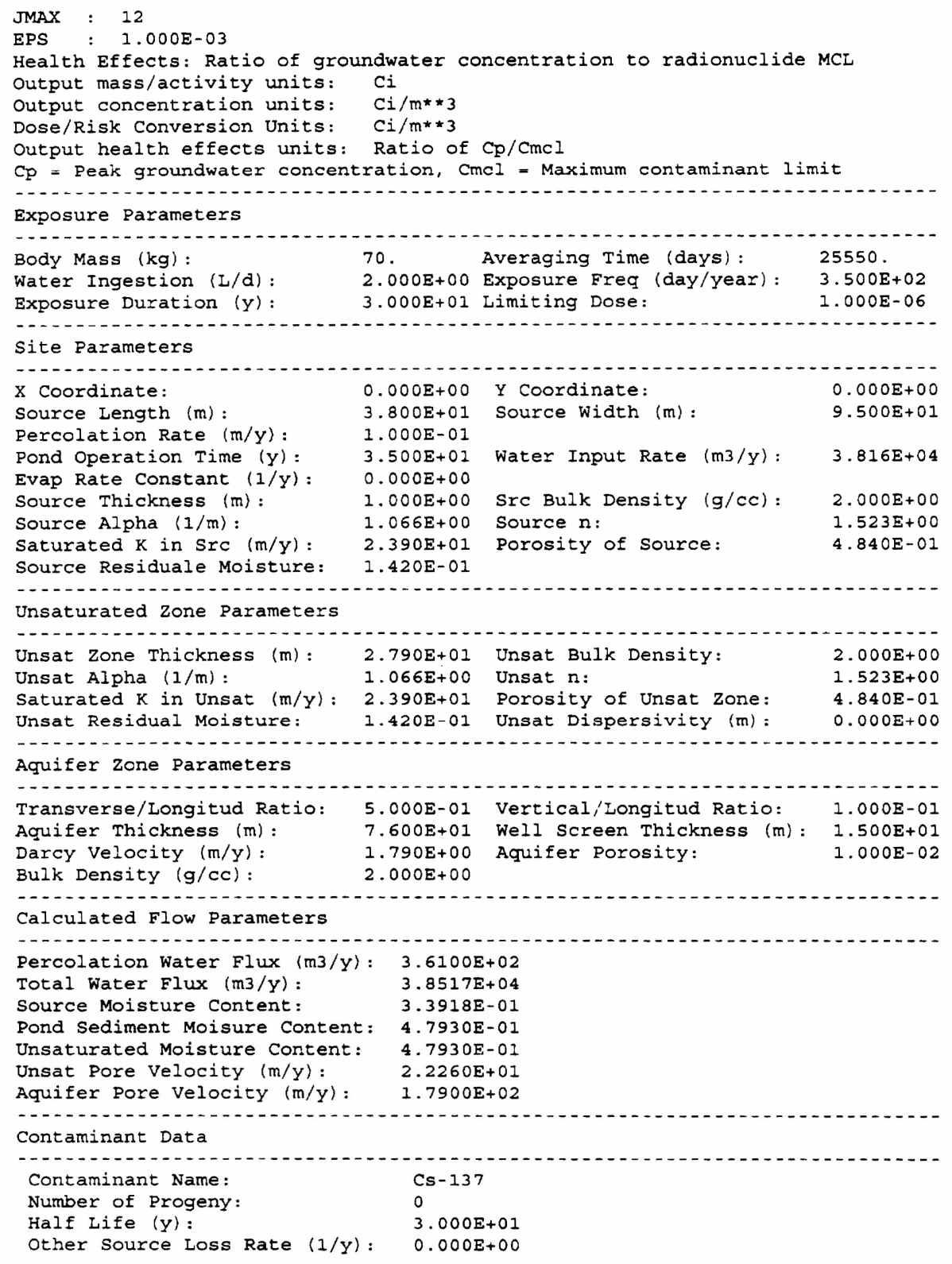




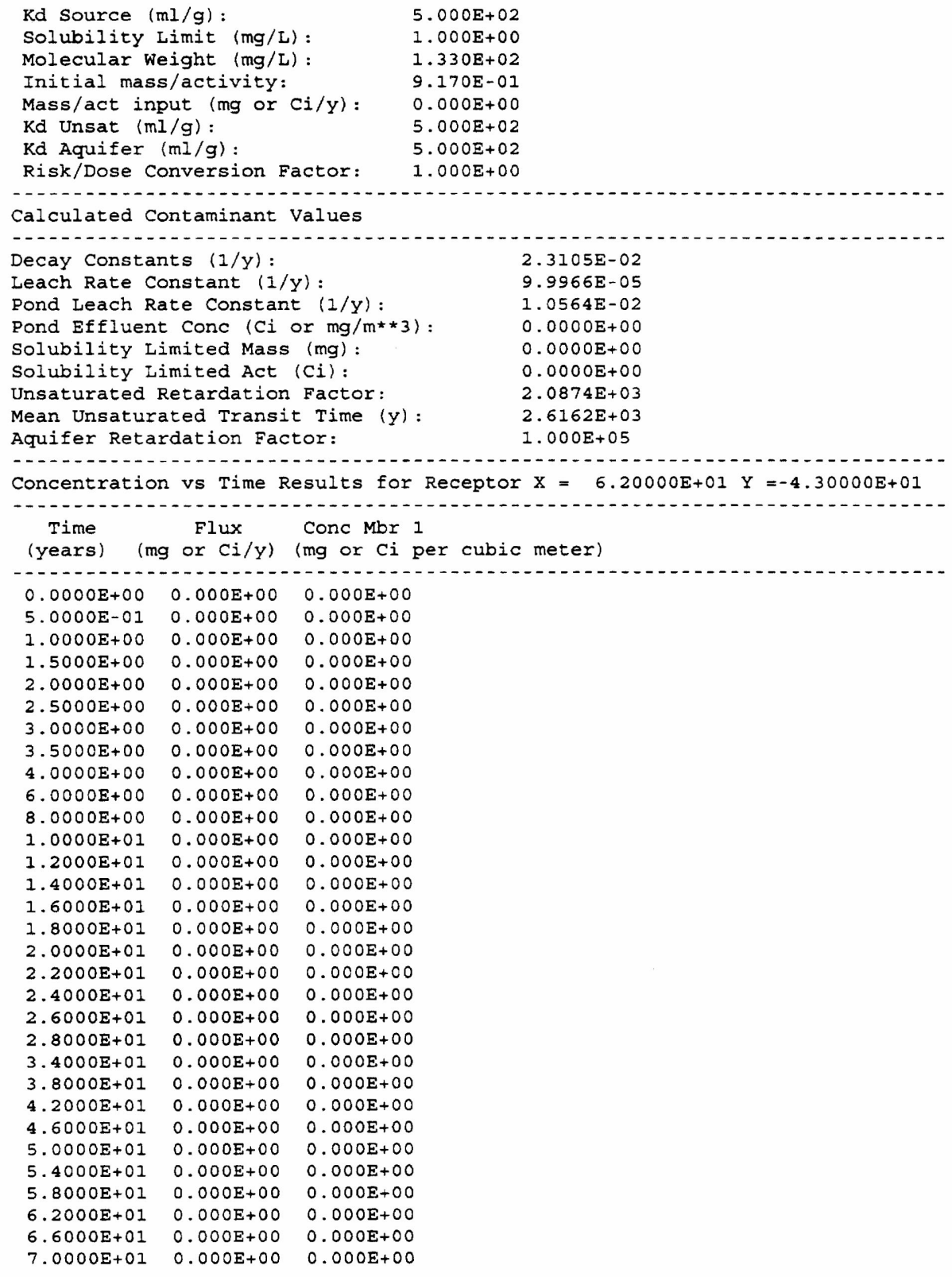




$\begin{array}{lll}7.4000 E+01 & 0.000 E+00 & 0.000 E+00 \\ 8.5000 E+01 & 0.000 E+00 & 0.000 E+00 \\ 9.0000 E+01 & 0.000 E+00 & 0.000 E+00 \\ 9.5000 E+01 & 0.000 E+00 & 0.000 E+00 \\ 1.0000 E+02 & 0.000 E+00 & 0.000 E+00 \\ 1.0500 E+02 & 0.000 E+00 & 0.000 E+00 \\ 1.1000 E+02 & 0.000 E+00 & 0.000 E+00 \\ 1.1500 E+02 & 0.000 E+00 & 0.000 E+00 \\ 1.2000 E+02 & 0.000 E+00 & 0.000 E+00 \\ 1.2500 E+02 & 0.000 E+00 & 0.000 E+00 \\ 1.3000 E+02 & 0.000 E+00 & 0.000 E+00 \\ 1.3500 E+02 & 0.000 E+00 & 0.000 E+00 \\ 1.4000 E+02 & 0.000 E+00 & 0.000 E+00 \\ 1.4500 E+02 & 0.000 E+00 & 0.000 E+00 \\ 1.5000 E+02 & 0.000 E+00 & 0.000 E+00 \\ 1.5500 E+02 & 0.000 E+00 & 0.000 E+00 \\ 1.6000 E+02 & 0.000 E+00 & 0.000 E+00 \\ 1.6500 E+02 & 0.000 E+00 & 0.000 E+00 \\ 1.7000 E+02 & 0.000 E+00 & 0.000 E+00 \\ 1.7500 E+02 & 0.000 E+00 & 0.000 E+00 \\ 1.8000 E+02 & 0.000 E+00 & 0.000 E+00 \\ 1.8500 E+02 & 0.000 E+00 & 0.000 E+00 \\ 1.9000 E+02 & 0.000 E+00 & 0.000 E+00 \\ 1.9500 E+02 & 0.000 E+00 & 0.000 E+00 \\ 2.1000 E+02 & 0.000 E+00 & 0.000 E+00 \\ 2.2000 E+02 & 0.000 E+00 & 0.000 E+00 \\ 2.3000 E+02 & 0.000 E+00 & 0.000 E+00 \\ 2.4000 E+02 & 0.000 E+00 & 0.000 E+00 \\ 2.5000 E+02 & 0.000 E+00 & 0.000 E+00 \\ 2.6000 E+02 & 0.000 E+00 & 0.000 E+00 \\ 2.7000 E+02 & 0.000 E+00 & 0.000 E+00 \\ 2.8000 E+02 & 0.000 E+00 & 0.000 E+00 \\ 2.9000 E+02 & 0.000 E+00 & 0.000 E+00 \\ 3.0000 E+02 & 0.000 E+00 & 0.000 E+00 \\ 3.1000 E+02 & 0.000 E+00 & 0.000 E+00 \\ 3.2000 E+02 & 0.000 E+00 & 0.000 E+00 \\ 3.3000 E+02 & 0.000 E+00 & 0.000 E+00 \\ 3.4000 E+02 & 0.000 E+00 & 0.000 E+00 \\ 3.5000 E+02 & 0.000 E+00 & 0.000 E+00 \\ 3.6000 E+02 & 0.000 E+00 & 0.000 E+00 \\ 3.7000 E+02 & 0.000 E+00 & 0.000 E+00 \\ 3.8000 E+02 & 0.000 E+00 & 0.000 E+00 \\ 3.9000 E+02 & 0.000 E+00 & 0.000 E+00 \\ 4.0000 E+02 & 0.000 E+00 & 0.000 E+00 \\ 4.1000 E+02 & 0.000 E+00 & 0.000 E+00 \\ 4.2000 E+02 & 0.000 E+00 & 0.000 E+00 \\ 4.3000 E+02 & 0.000 E+00 & 0.000 E+00 \\ 4.4000 E+02 & 0.000 E+00 & 0.000 E+00 \\ 4.5000 E+02 & 0.000 E+00 & 0.000 E+00 \\ 4.6000 E+02 & 0.000 E+00 & 0.000 E+00 \\ 4.7000 E+02 & 0.000 E+00 & 0.000 E+00 \\ 4.8000 E+02 & 0.000 E+00 & 0.000 E+00 \\ 4.9000 E+02 & 0.000 E+00 & 0.000 E+00 \\ 5.2500 E+02 & 0.000 E+00 & 0.000 E+00 \\ 5.5000 E+02 & 0.000 E+00 & 0.000 E+00 \\ 5.7500 E+02 & 0.000 E+00 & 0.000 E+00 \\ 6.0000 E+02 & 0.000 E+00 & 0.000 E+00\end{array}$




$\begin{array}{lll}6.2500 E+02 & 0.000 E+00 & 0.000 E+00 \\ 6.5000 E+02 & 0.000 E+00 & 0.000 E+00 \\ 6.7500 E+02 & 0.000 E+00 & 0.000 E+00 \\ 7.0000 E+02 & 0.000 E+00 & 0.000 E+00 \\ 7.2500 E+02 & 0.000 E+00 & 0.000 E+00 \\ 7.5000 E+02 & 0.000 E+00 & 0.000 E+00 \\ 7.7500 E+02 & 0.000 E+00 & 0.000 E+00 \\ 8.0000 E+02 & 0.000 E+00 & 0.000 E+00 \\ 8.2500 E+02 & 0.000 E+00 & 0.000 E+00 \\ 8.5000 E+02 & 0.000 E+00 & 0.000 E+00 \\ 8.7500 E+02 & 0.000 E+00 & 0.000 E+00 \\ 9.0000 E+02 & 0.000 E+00 & 0.000 E+00 \\ 9.2500 E+02 & 0.000 E+00 & 0.000 E+00 \\ 9.5000 E+02 & 0.000 E+00 & 0.000 E+00 \\ 9.7500 E+02 & 0.000 E+00 & 0.000 E+00\end{array}$

Maximum Concentration and Time for Member \#1: $0.000 E+00 \quad 0.000 E+00$

Maximum Average Concentration Between $0.0000 \mathrm{E}+00$ and $3.0000 \mathrm{E}+01$ years: $0.000 \mathrm{E}+00$

Concentration vs The Results for Receptor Concentration vs Time Results for Receptor $X=1.58098 E+02 Y=-3.72380 E+02$ Concentrat

Time Flux Conc Mbr 1

(years) (mg or $\mathrm{Ci} / \mathrm{Y}$ ) (mg or $\mathrm{Ci}$ per cubic meter)

$\begin{array}{lll}0.0000 E+00 & 0.000 E+00 & 0.000 E+00 \\ 5.0000 E-01 & 0.000 E+00 & 0.000 E+00 \\ 1.0000 E+00 & 0.000 E+00 & 0.000 E+00 \\ 1.5000 E+00 & 0.000 E+00 & 0.000 E+00 \\ 2.0000 E+00 & 0.000 E+00 & 0.000 E+00 \\ 2.5000 E+00 & 0.000 E+00 & 0.000 E+00 \\ 3.0000 E+00 & 0.000 E+00 & 0.000 E+00 \\ 3.5000 E+00 & 0.000 E+00 & 0.000 E+00 \\ 4.0000 E+00 & 0.000 E+00 & 0.000 E+00 \\ 6.0000 E+00 & 0.000 E+00 & 0.000 E+00 \\ 8.0000 E+00 & 0.000 E+00 & 0.000 E+00 \\ 1.0000 E+01 & 0.000 E+00 & 0.000 E+00 \\ 1.2000 E+01 & 0.000 E+00 & 0.000 E+00 \\ 1.4000 E+01 & 0.000 E+00 & 0.000 E+00 \\ 1.6000 E+01 & 0.000 E+00 & 0.000 E+00 \\ 1.8000 E+01 & 0.000 E+00 & 0.000 E+00 \\ 2.0000 E+01 & 0.000 E+00 & 0.000 E+00 \\ 2.2000 E+01 & 0.000 E+00 & 0.000 E+00 \\ 2.4000 E+01 & 0.000 E+00 & 0.000 E+00 \\ 2.6000 E+01 & 0.000 E+00 & 0.000 E+00 \\ 2.8000 E+01 & 0.000 E+00 & 0.000 E+00 \\ 3.4000 E+01 & 0.000 E+00 & 0.000 E+00 \\ 3.8000 E+01 & 0.000 E+00 & 0.000 E+00 \\ 4.2000 E+01 & 0.000 E+00 & 0.000 E+00 \\ 4.6000 E+01 & 0.000 E+00 & 0.000 E+00 \\ 5.0000 E+01 & 0.000 E+00 & 0.000 E+00 \\ 5.4000 E+01 & 0.000 E+00 & 0.000 E+00 \\ 5.8000 E+01 & 0.000 E+00 & 0.000 E+00 \\ 6.2000 E+01 & 0.000 E+00 & 0.000 E+00 \\ 6.6000 E+01 & 0.000 E+00 & 0.000 E+00 \\ 7.0000 E+01 & 0.000 E+00 & 0.000 E+00 \\ 7.4000 E+01 & 0.000 E+00 & 0.000 E+00 \\ 8.5000 E+01 & 0.000 E+00 & 0.000 E+00 \\ & \end{array}$




$\begin{array}{lll}9.0000 E+01 & 0.000 E+00 & 0.000 E+00 \\ 9.5000 E+01 & 0.000 E+00 & 0.000 E+00 \\ 1.0000 E+02 & 0.000 E+00 & 0.000 E+00 \\ 1.0500 E+02 & 0.000 E+00 & 0.000 E+00 \\ 1.1000 E+02 & 0.000 E+00 & 0.000 E+00 \\ 1.1500 E+02 & 0.000 E+00 & 0.000 E+00 \\ 1.2000 E+02 & 0.000 E+00 & 0.000 E+00 \\ 1.2500 E+02 & 0.000 E+00 & 0.000 E+00 \\ 1.3000 E+02 & 0.000 E+00 & 0.000 E+00 \\ 1.3500 E+02 & 0.000 E+00 & 0.000 E+00 \\ 1.4000 E+02 & 0.000 E+00 & 0.000 E+00 \\ 1.4500 E+02 & 0.000 E+00 & 0.000 E+00 \\ 1.5000 E+02 & 0.000 E+00 & 0.000 E+00 \\ 1.5500 E+02 & 0.000 E+00 & 0.000 E+00 \\ 1.6000 E+02 & 0.000 E+00 & 0.000 E+00 \\ 1.6500 E+02 & 0.000 E+00 & 0.000 E+00 \\ 1.7000 E+02 & 0.000 E+00 & 0.000 E+00 \\ 1.7500 E+02 & 0.000 E+00 & 0.000 E+00 \\ 1.8000 E+02 & 0.000 E+00 & 0.000 E+00 \\ 1.8500 E+02 & 0.000 E+00 & 0.000 E+00 \\ 1.9000 E+02 & 0.000 E+00 & 0.000 E+00 \\ 1.9500 E+02 & 0.000 E+00 & 0.000 E+00 \\ 2.1000 E+02 & 0.000 E+00 & 0.000 E+00 \\ 2.2000 E+02 & 0.000 E+00 & 0.000 E+00 \\ 2.3000 E+02 & 0.000 E+00 & 0.000 E+00 \\ 2.4000 E+02 & 0.000 E+00 & 0.000 E+00 \\ 2.5000 E+02 & 0.000 E+00 & 0.000 E+00 \\ 2.6000 E+02 & 0.000 E+00 & 0.000 E+00 \\ 2.7000 E+02 & 0.000 E+00 & 0.000 E+00 \\ 2.8000 E+02 & 0.000 E+00 & 0.000 E+00 \\ 2.9000 E+02 & 0.000 E+00 & 0.000 E+00 \\ 3.0000 E+02 & 0.000 E+00 & 0.000 E+00 \\ 3.1000 E+02 & 0.000 E+00 & 0.000 E+00 \\ 3.2000 E+02 & 0.000 E+00 & 0.000 E+00 \\ 3.3000 E+02 & 0.000 E+00 & 0.000 E+00 \\ 3.4000 E+02 & 0.000 E+00 & 0.000 E+00 \\ 3.5000 E+02 & 0.000 E+00 & 0.000 E+00 \\ 3.6000 E+02 & 0.000 E+00 & 0.000 E+00 \\ 3.7000 E+02 & 0.000 E+00 & 0.000 E+00 \\ 3.8000 E+02 & 0.000 E+00 & 0.000 E+00 \\ 3.9000 E+02 & 0.000 E+00 & 0.000 E+00 \\ 4.0000 E+02 & 0.000 E+00 & 0.000 E+00 \\ 4.1000 E+02 & 0.000 E+00 & 0.000 E+00 \\ 4.2000 E+02 & 0.000 E+00 & 0.000 E+00 \\ 4.3000 E+02 & 0.000 E+00 & 0.000 E+00 \\ 4.4000 E+02 & 0.000 E+00 & 0.000 E+00 \\ 4.5000 E+02 & 0.000 E+00 & 0.000 E+00 \\ 4.6000 E+02 & 0.000 E+00 & 0.000 E+00 \\ 4.7000 E+02 & 0.000 E+00 & 0.000 E+00 \\ 4.8000 E+02 & 0.000 E+00 & 0.000 E+00 \\ 5.2500 E+02 & 0.000 E+00 & 0.000 E+00 \\ 6.5000 E+02 & 0.000 E+00 & 0.000 E+00\end{array}$




$\begin{array}{lll}6.7500 E+02 & 0.000 E+00 & 0.000 E+00 \\ 7.0000 E+02 & 0.000 E+00 & 0.000 E+00 \\ 7.2500 E+02 & 0.000 E+00 & 0.000 E+00 \\ 7.5000 E+02 & 0.000 E+00 & 0.000 E+00 \\ 7.7500 E+02 & 0.000 E+00 & 0.000 E+00 \\ 8.0000 E+02 & 0.000 E+00 & 0.000 E+00 \\ 8.2500 E+02 & 0.000 E+00 & 0.000 E+00 \\ 8.5000 E+02 & 0.000 E+00 & 0.000 E+00 \\ 8.7500 E+02 & 0.000 E+00 & 0.000 E+00 \\ 9.0000 E+02 & 0.000 E+00 & 0.000 E+00 \\ 9.2500 E+02 & 0.000 E+00 & 0.000 E+00 \\ 9.5000 E+02 & 0.000 E+00 & 0.000 E+00 \\ 9.7500 E+02 & 0.000 E+00 & 0.000 E+00\end{array}$

Maximum Concentration and Time for Member \#1: $0.000 E+00 \quad 0.000 E+00$

Maximum Average Concentration Between $0.0000 E+00$ and $3.0000 E+01$ years: $0.000 \mathrm{E}+00$

Concentration vs Time Results for Receptor $X=0.00000 E+00 Y=0.00000 E+00$

Concent....

Time Flux Conc Mbr 1

(years) (mg or $\mathrm{Ci} / \mathrm{y}$ ) (mg or $\mathrm{Ci}$ per cubic meter)

(years)

$0.0000 \mathrm{E}+00 \quad 0.000 \mathrm{E}+00 \quad 0.000 \mathrm{E}+00$

$\begin{array}{lll}5.0000 E-01 & 0.000 E+00 & 0.000 E+00\end{array}$

$1.0000 E+00 \quad 0.000 E+00 \quad 0.000 E+00$

$1.5000 E+00 \quad 0.000 E+00 \quad 0.000 E+00$

$2.0000 E+00 \quad 0.000 E+00 \quad 0.000 E+00$

$2.5000 E+00 \quad 0.000 E+00 \quad 0.000 E+00$

$3.0000 E+00 \quad 0.000 E+00 \quad 0.000 E+00$

$3.5000 E+00 \quad 0.000 E+00 \quad 0.000 E+00$

$4.0000 \mathrm{E}+00 \quad 0.000 \mathrm{E}+00 \quad 0.000 \mathrm{E}+00$

$6.0000 E+00 \quad 0.000 E+00 \quad 0.000 E+00$

$8.0000 E+00 \quad 0.000 E+00 \quad 0.000 E+00$

$1.0000 E+01 \quad 0.000 E+00 \quad 0.000 E+00$

$1.2000 E+01 \quad 0.000 E+00 \quad 0.000 E+00$

$1.4000 E+01 \quad 0.000 E+00 \quad 0.000 E+00$

$1.6000 \mathrm{E}+01 \quad 0.000 \mathrm{E}+00 \quad 0.000 \mathrm{E}+00$

$1.8000 E+01 \quad 0.000 E+00 \quad 0.000 E+00$

$2.0000 E+01 \quad 0.000 E+00 \quad 0.000 E+00$

$2.2000 E+01 \quad 0.000 E+00 \quad 0.000 E+00$

$2.4000 E+01 \quad 0.000 E+00 \quad 0.000 E+00$

$2.6000 E+01 \quad 0.000 E+00 \quad 0.000 E+00$

$2.8000 E+01 \quad 0.000 E+00 \quad 0.000 E+00$

$3.4000 E+01 \quad 0.000 E+00 \quad 0.000 E+00$

$3.8000 E+01 \quad 0.000 E+00 \quad 0.000 E+00$

$4.2000 E+01 \quad 0.000 E+00 \quad 0.000 E+00$

$4.6000 E+01 \quad 0.000 E+00 \quad 0.000 E+00$

$5.0000 E+01 \quad 0.000 E+00 \quad 0.000 E+00$

$5.4000 \mathrm{E}+01 \quad 0.000 \mathrm{E}+00 \quad 0.000 \mathrm{E}+00$

$5.8000 E+01 \quad 0.000 E+00 \quad 0.000 E+00$

$6.2000 \mathrm{E}+01 \quad 0.000 \mathrm{E}+00 \quad 0.000 \mathrm{E}+00$

$6.6000 E+01 \quad 0.000 E+00 \quad 0.000 E+00$

$\begin{array}{lll}7.0000 E+01 & 0.000 E+00 & 0.000 E+00\end{array}$

$\begin{array}{lll}7.4000 E+01 & 0.000 E+00 & 0.000 E+00\end{array}$

$8.5000 E+01 \quad 0.000 E+00 \quad 0.000 E+00$

$9.0000 E+01 \quad 0.000 E+00 \quad 0.000 E+00$

$9.5000 E+01 \quad 0.000 E+00 \quad 0.000 E+00$ 


$\begin{array}{lll}1.0000 E+02 & 0.000 E+00 & 0.000 E+00 \\ 1.0500 E+02 & 0.000 E+00 & 0.000 E+00 \\ 1.1000 E+02 & 0.000 E+00 & 0.000 E+00 \\ 1.1500 E+02 & 0.000 E+00 & 0.000 E+00 \\ 1.2000 E+02 & 0.000 E+00 & 0.000 E+00 \\ 1.2500 E+02 & 0.000 E+00 & 0.000 E+00 \\ 1.3000 E+02 & 0.000 E+00 & 0.000 E+00 \\ 1.3500 E+02 & 0.000 E+00 & 0.000 E+00 \\ 1.4000 E+02 & 0.000 E+00 & 0.000 E+00 \\ 1.4500 E+02 & 0.000 E+00 & 0.000 E+00 \\ 1.5000 E+02 & 0.000 E+00 & 0.000 E+00 \\ 1.5500 E+02 & 0.000 E+00 & 0.000 E+00 \\ 1.6000 E+02 & 0.000 E+00 & 0.000 E+00 \\ 1.6500 E+02 & 0.000 E+00 & 0.000 E+00 \\ 1.7000 E+02 & 0.000 E+00 & 0.000 E+00 \\ 1.7500 E+02 & 0.000 E+00 & 0.000 E+00 \\ 1.8000 E+02 & 0.000 E+00 & 0.000 E+00 \\ 1.8500 E+02 & 0.000 E+00 & 0.000 E+00 \\ 1.9000 E+02 & 0.000 E+00 & 0.000 E+00 \\ 1.9500 E+02 & 0.000 E+00 & 0.000 E+00 \\ 2.1000 E+02 & 0.000 E+00 & 0.000 E+00 \\ 2.2000 E+02 & 0.000 E+00 & 0.000 E+00 \\ 2.3000 E+02 & 0.000 E+00 & 0.000 E+00 \\ 2.4000 E+02 & 0.000 E+00 & 0.000 E+00 \\ 2.5000 E+02 & 0.000 E+00 & 0.000 E+00 \\ 2.6000 E+02 & 0.000 E+00 & 0.000 E+00 \\ 2.7000 E+02 & 0.000 E+00 & 0.000 E+00 \\ 2.8000 E+02 & 0.000 E+00 & 0.000 E+00 \\ 2.9000 E+02 & 0.000 E+00 & 0.000 E+00 \\ 3.0000 E+02 & 0.000 E+00 & 0.000 E+00 \\ 3.1000 E+02 & 0.000 E+00 & 0.000 E+00 \\ 3.2000 E+02 & 0.000 E+00 & 0.000 E+00 \\ 3.3000 E+02 & 0.000 E+00 & 0.000 E+00 \\ 3.4000 E+02 & 0.000 E+00 & 0.000 E+00 \\ 3.5000 E+02 & 0.000 E+00 & 0.000 E+00 \\ 3.6000 E+02 & 0.000 E+00 & 0.000 E+00 \\ 3.7000 E+02 & 0.000 E+00 & 0.000 E+00 \\ 3.8000 E+02 & 0.000 E+00 & 0.000 E+00 \\ 3.9000 E+02 & 0.000 E+00 & 0.000 E+00 \\ 4.0000 E+02 & 0.000 E+00 & 0.000 E+00 \\ 4.1000 E+02 & 0.000 E+00 & 0.000 E+00 \\ 4.2000 E+02 & 0.000 E+00 & 0.000 E+00 \\ 4.3000 E+02 & 0.000 E+00 & 0.000 E+00 \\ 4.4000 E+02 & 0.000 E+00 & 0.000 E+00 \\ 4.5000 E+02 & 0.000 E+00 & 0.000 E+00 \\ 4.6000 E+02 & 0.000 E+00 & 0.000 E+00 \\ 4.7000 E+02 & 0.000 E+00 & 0.000 E+00 \\ 4.8000 E+02 & 0.000 E+00 & 0.000 E+00 \\ 4.9000 E+02 & 0.000 E+00 & 0.000 E+00 \\ 5.2500 E+02 & 0.000 E+00 & 0.000 E+00 \\ 5.5000 E+02 & 0.000 E+00 & 0.000 E+00 \\ 5.7500 E+02 & 0.000 E+00 & 0.000 E+00 \\ 6.0000 E+02 & 0.000 E+00 & 0.000 E+00 \\ 6.2500 E+02 & 0.000 E+00 & 0.000 E+00 \\ 6.5000 E+02 & 0.000 E+00 & 0.000 E+00 \\ 7.0000 E+02 & 0.000 E+00 & 0.000 E+00\end{array}$




\begin{tabular}{|c|c|c|}
\hline & $0.000 \mathrm{E}+00$ & $0.000 \mathrm{E}+00$ \\
\hline & $0.000 \mathrm{E}+00$ & $0.000 \mathrm{E}+0.0$ \\
\hline 02 & $0.000 E+00$ & $0.000 E+00$ \\
\hline$E+02$ & $0.000 E+00$ & $0.000 E+00$ \\
\hline 2 & $0.000 E+00$ & $0.000 \mathrm{E}+00$ \\
\hline 8.500 & $0.000 \mathrm{E}+00$ & $0.000 E+00$ \\
\hline $8.7500 \mathrm{E}+02$ & $0.000 \mathrm{E}+00$ & $0.000 E+00$ \\
\hline $9.0000 E+02$ & $0.000 E+00$ & $0.000 \mathrm{E}+00$ \\
\hline $9.2500 E+02$ & $0.000 \mathrm{E}+00$ & $0.000 E+00$ \\
\hline $9.5000 \mathrm{E}+02$ & $0.000 E+00$ & $0.000 \mathrm{E}+00$ \\
\hline $9.7500 E+02$ & $0.000 E+00$ & $0.000 \mathrm{E}+00$ \\
\hline
\end{tabular}

Maximum Concentration and Time for Member \#1: $0.000 \mathrm{E}+00 \quad 0.000 \mathrm{E}+00$

Maximum Average Concentration Between $0.0000 \mathrm{E}+00$ and $3.0000 \mathrm{E}+01$ years: $0.000 \mathrm{E}+00$

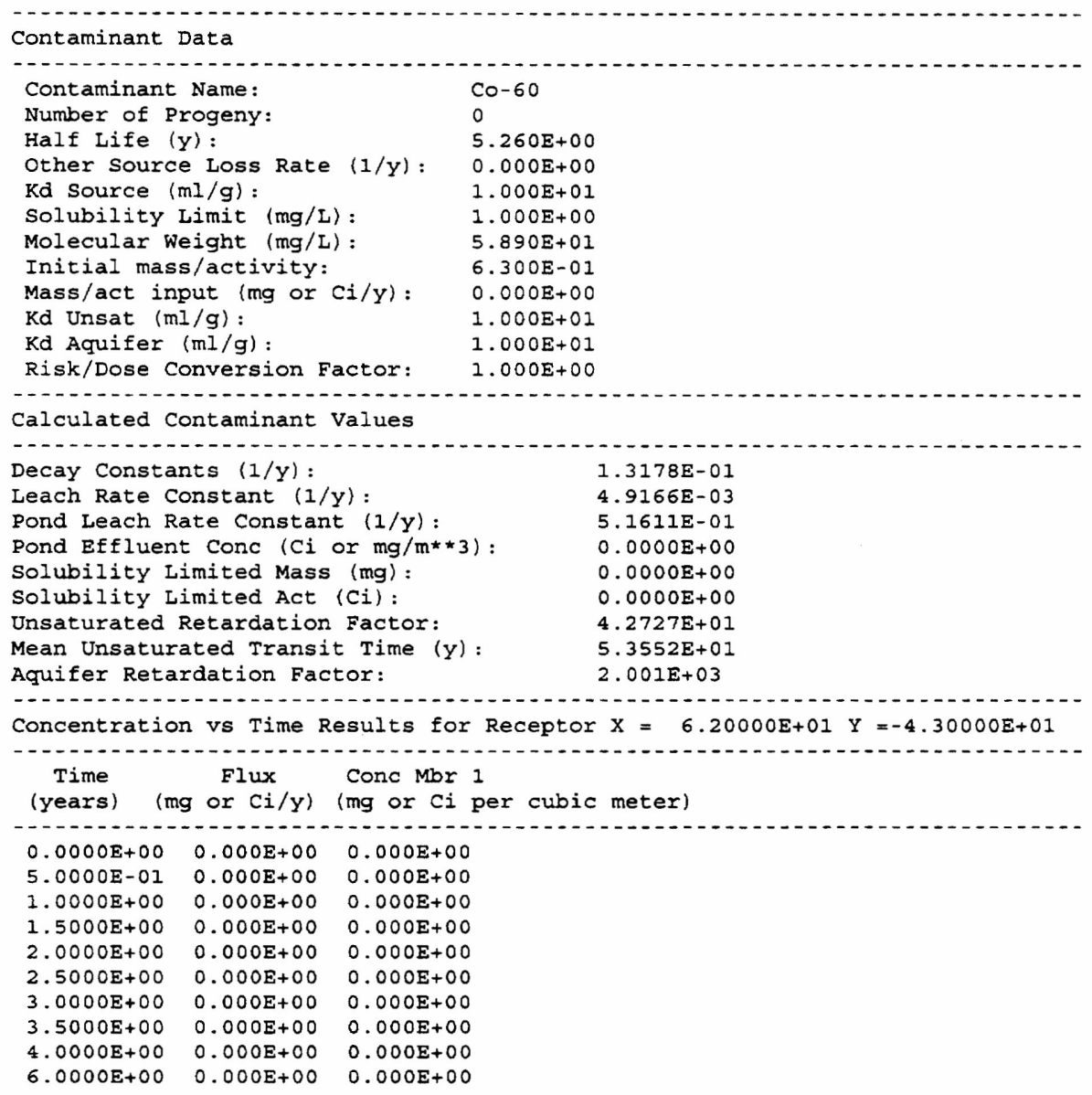




\begin{tabular}{|c|c|c|}
\hline $8.0000 E+00$ & $0.000 E+00$ & $0.000 E+00$ \\
\hline $.0000 E+01$ & $0.000 E+00$ & $0.000 E+00$ \\
\hline $2000 E+01$ & $0.000 E+00$ & $0.000 E+00$ \\
\hline $4000 E+01$ & $0.000 E+00$ & $0.000 E+00$ \\
\hline $1.6000 \mathrm{E}+01$ & $0.000 \mathrm{E}+00$ & $0.000 \mathrm{E}+00$ \\
\hline $1.8000 E+01$ & $0.000 \mathrm{E}+00$ & $0.000 E+00$ \\
\hline $.0000 E+01$ & $0.000 E+00$ & $0.000 E+00$ \\
\hline $2000 E+01$ & $0.000 E+00$ & $0.000 E+00$ \\
\hline $2.4000 E+01$ & $0.000 E+00$ & $0.000 E+00$ \\
\hline $2.6000 \mathrm{E}+01$ & $0.000 E+00$ & $0.000 \mathrm{E}+00$ \\
\hline $2.8000 E+01$ & $0.000 \mathrm{E}+00$ & $0.000 E+00$ \\
\hline $3.4000 E+01$ & $0.000 E+00$ & $0.000 \mathrm{E}+00$ \\
\hline $3.8000 \mathrm{E}+01$ & $0.000 E+00$ & $0.000 E+00$ \\
\hline $4.2000 E+01$ & $0.000 E+00$ & $0.000 E+00$ \\
\hline $4.6000 E+01$ & $0.000 E+00$ & $0.000 \mathrm{E}+00$ \\
\hline $5.0000 E+01$ & $0.000 E+00$ & $0.000 E+00$ \\
\hline $5.4000 E+01$ & $2.095 E-04$ & $0.000 E+00$ \\
\hline $.8000 E+01$ & $1.569 \mathrm{E}-05$ & $0.000 E+00$ \\
\hline $6.2000 E+01$ & $1.175 \mathrm{E}-06$ & $0.000 E+00$ \\
\hline $6.6000 E+01$ & $8.805 E-08$ & 0.00 \\
\hline $7.0000 E+01$ & $6.595 E-09$ & $0.000 E+00$ \\
\hline $7.4000 E+01$ & $4.940 E-10$ & $0.000 E+00$ \\
\hline $8.5000 E+01$ & $3.969 \mathrm{E}-13$ & $0.000 \mathrm{E}+00$ \\
\hline $9.0000 \mathrm{E}+01$ & $3.106 E-16$ & $0.000 E+00$ \\
\hline $9.5000 E+01$ & 1. $568 \mathrm{E}-16$ & 1. $125 E-28$ \\
\hline $1.0000 \mathrm{E}+02$ & $7.917 E-17$ & $3.546 E-27$ \\
\hline $1.0500 \mathrm{E}+02$ & $3.997 E-17$ & $5.041 E-26$ \\
\hline $1.1000 \mathrm{E}+02$ & $2.018 \mathrm{E}-17$ & 3.98 \\
\hline $1.1500 \mathrm{E}+02$ & $1.019 \mathrm{E}-17$ & $E-24$ \\
\hline $1.2000 E+02$ & $5.143 E-18$ & 7.23 \\
\hline $1.2500 E+02$ & $2.597 E-18$ & $1.973 E-23$ \\
\hline $1.3000 \mathrm{E}+02$ & $1.311 E-18$ & $4.322 E-23$ \\
\hline $1.3500 E+02$ & $6.619 E-19$ & $7.912 E-23$ \\
\hline $1.4000 \mathrm{E}+02$ & $3.342 \mathrm{E}-19$ & 1. $249 \mathrm{E}-22$ \\
\hline $1.4500 E+02$ & $1.687 \mathrm{E}-19$ & $1.741 E-22$ \\
\hline 1. $5000 \mathrm{E}+02$ & $8.517 E-20$ & $2.185 \mathrm{E}-22$ \\
\hline 1. $5500 \mathrm{E}+02$ & $4.300 E-20$ & $2.509 E-22$ \\
\hline $1.6000 E+02$ & $2.171 E-20$ & $2.668 \mathrm{E}-22$ \\
\hline $1.6500 E+02$ & $1.096 \mathrm{E}-20$ & $2.654 \mathrm{E}-22$ \\
\hline $1.7000 \mathrm{E}+02$ & $5.533 E-21$ & $2.493 E-22$ \\
\hline $1.7500 E+02$ & $2.794 E-21$ & $2.225 E-22$ \\
\hline $1.8000 E+02$ & $1.410 E-21$ & $1.900 \mathrm{E}-22$ \\
\hline $1.8500 E+02$ & $7.121 E-22$ & 1. $559 \mathrm{E}-22$ \\
\hline $1.9000 \mathrm{E}+02$ & $3.595 \mathrm{E}-22$ & 1. $235 \mathrm{E}-22$ \\
\hline $1.9500 E+02$ & $1.815 \mathrm{E}-22$ & $9.482 \mathrm{E}-23$ \\
\hline $2.1000 E+02$ & $2.335 E-23$ & $3.662 E-23$ \\
\hline $2.2000 \mathrm{E}+02$ & $5.953 E-24$ & $1.743 E-23$ \\
\hline $2.3000 E+02$ & $1.517 \mathrm{E}-24$ & $7.743 E-24$ \\
\hline $2.4000 \mathrm{E}+02$ & $3.867 E-25$ & $3.245 E-24$ \\
\hline $2.5000 E+02$ & $9.857 E-26$ & 1. $295 E-24$ \\
\hline $2.6000 \mathrm{E}+02$ & $2.513 E-26$ & $4.954 E-25$ \\
\hline $2.7000 E+02$ & $6.404 E-27$ & $1.828 E-25$ \\
\hline $2.8000 E+02$ & $1.632 E-27$ & $6.539 E-26$ \\
\hline $2.9000 E+02$ & $4.161 E-28$ & $2.276 E-26$ \\
\hline $3.0000 E+02$ & $1.060 E-28$ & $7.754 E-27$ \\
\hline $3.1000 E+02$ & $2.703 E-29$ & $2.577 E-27$ \\
\hline $3.2000 E+02$ & $6.890 E-30$ & $8.428 E-28$ \\
\hline
\end{tabular}




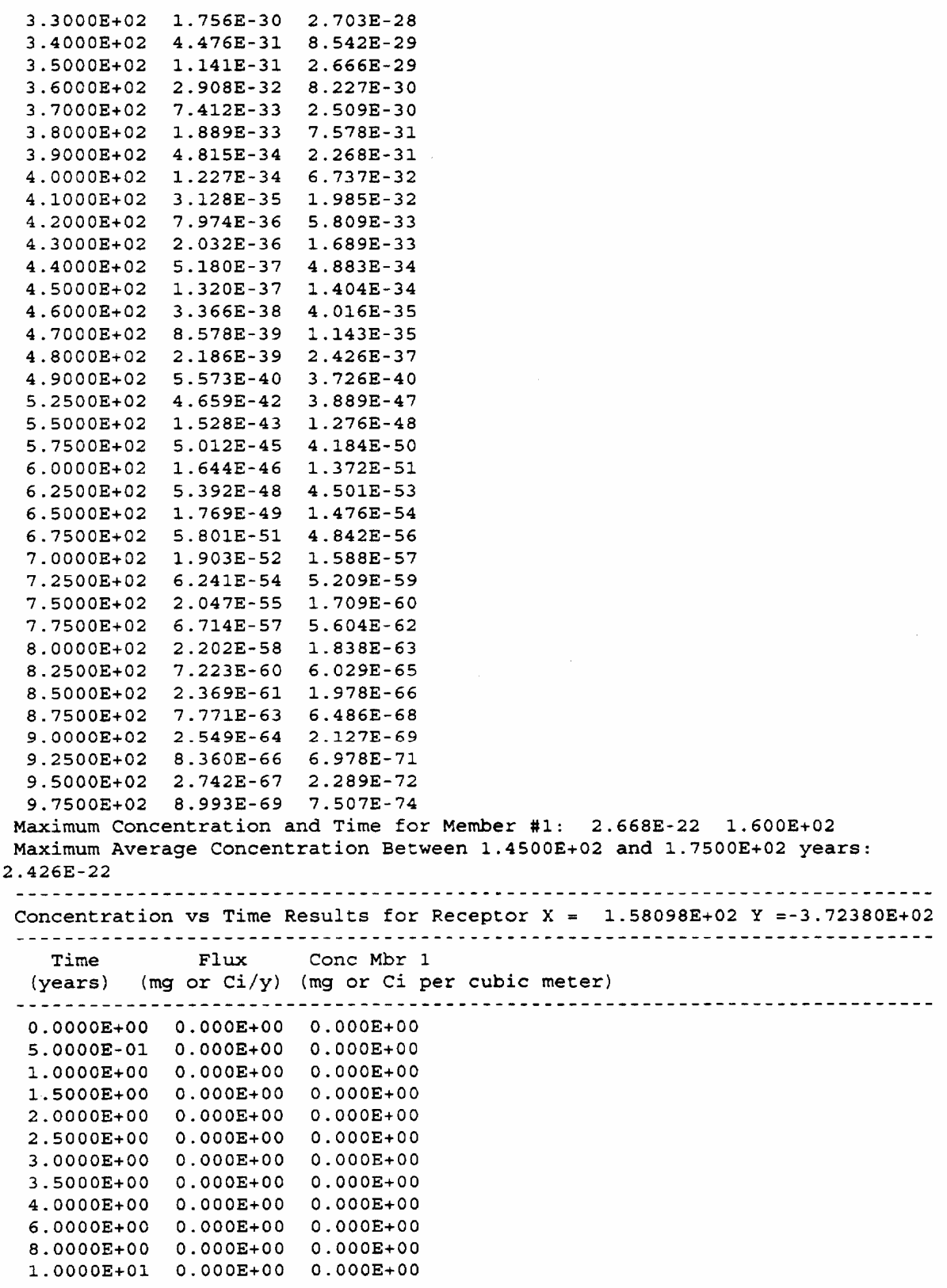




\begin{tabular}{|c|c|c|}
\hline $.2000 E+01$ & $0.000 \mathrm{E}+00$ & $0.000 E+00$ \\
\hline $.4000 E+01$ & $0.000 E+00$ & $0.000 E+00$ \\
\hline $1.6000 \mathrm{E}+01$ & $0.000 E+00$ & $0.000 E+00$ \\
\hline $1.8000 E+01$ & $0.000 \mathrm{E}+00$ & $0.000 E+00$ \\
\hline $2.0000 E+01$ & $0.000 \mathrm{E}+00$ & $0.000 E+00$ \\
\hline $2.2000 E+01$ & $0.000 \mathrm{E}+00$ & $0.000 E+00$ \\
\hline $2.4000 E+02$ & $0.000 E+00$ & $0.000 E+00$ \\
\hline $2.6000 \mathrm{E}+01$ & $0.000 \mathrm{E}+00$ & $0.000 E+00$ \\
\hline $2.8000 E+01$ & $0.000 \mathrm{E}+00$ & $0.000 E+00$ \\
\hline $3.4000 E+01$ & $0.000 E+00$ & $0.000 E+00$ \\
\hline $3.8000 E+01$ & $0.000 E+00$ & $0.000 E+00$ \\
\hline $4.2000 E+01$ & $0.000 E+00$ & $0.000 E+00$ \\
\hline $4.6000 \mathrm{E}+01$ & $0.000 E+00$ & $0.000 \mathrm{E}+00$ \\
\hline $5.0000 E+01$ & $0.000 E+00$ & $0.000 \mathrm{E}+00$ \\
\hline $5.4000 E+01$ & $2.095 E-04$ & $0.000 \mathrm{E}+00$ \\
\hline $5.8000 E+01$ & 1. $569 E-05$ & $0.000 E+00$ \\
\hline $6.2000 E+01$ & 1.17 & $0.000 \mathrm{E}+00$ \\
\hline $6.6000 E+01$ & 8.80 & $0.000 E+00$ \\
\hline $7.0000 \mathrm{E}+01$ & 6.59 & $E+00$ \\
\hline $7.4000 E+01$ & $4.940 E-10$ & $0.000 E+00$ \\
\hline $8.5000 E+01$ & $3.969 E-13$ & $0.000 E+00$ \\
\hline $9.0000 E+01$ & $3.106 \mathrm{E}-16$ & $0.000 \mathrm{E}+00$ \\
\hline $9.5000 E+01$ & $1.568 E-16$ & $0.000 \mathrm{E}+00$ \\
\hline $1.0000 E+02$ & $7.917 \mathrm{E}-17$ & $0.000 E+00$ \\
\hline $1.0500 E+02$ & $3.997 \mathrm{E}-17$ & $0.000 E+00$ \\
\hline $1.1000 \mathrm{E}+02$ & $2.018 E-17$ & $0.000 E+00$ \\
\hline $1.1500 \mathrm{E}+02$ & $1.019 \mathrm{E}-17$ & $0.000 E+00$ \\
\hline $1.2000 E+02$ & $8-18$ & $E+00$ \\
\hline $1.2500 \mathrm{E}+02$ & $2.597 E-18$ & $0.000 E+00$ \\
\hline $1.3000 \mathrm{E}+02$ & $1.311 E-18$ & $0.000 E+00$ \\
\hline $1.3500 \mathrm{E}+02$ & $6.619 E-19$ & $0.000 E+00$ \\
\hline $1.4000 E+02$ & $3.342 E-19$ & $0.000 E+00$ \\
\hline $1.4500 E+02$ & $1.687 E-19$ & $E+00$ \\
\hline $1.5000 \mathrm{E}+02$ & $8.517 E-20$ & $0.000 E+00$ \\
\hline $1.5500 E+02$ & $4.300 \mathrm{E}-20$ & $E+00$ \\
\hline $1.6000 E+02$ & $2.171 E-20$ & $E+00$ \\
\hline $1.6500 E+02$ & $1.096 \mathrm{E}-20$ & $E+00$ \\
\hline $1.7000 E+02$ & $5.533 E-21$ & $0.000 E+00$ \\
\hline $1.7500 E+02$ & $2.794 E-21$ & $0.000 E+00$ \\
\hline $1.8000 \mathrm{E}+02$ & $1.410 \mathrm{E}-21$ & $0.000 E+00$ \\
\hline $1.8500 E+02$ & $7.121 \mathrm{E}-22$ & $0.000 E+00$ \\
\hline $1.9000 E+02$ & $3.595 E-22$ & $0.000 E+00$ \\
\hline $1.9500 \mathrm{E}+02$ & $1.815 E-22$ & $0.000 E+00$ \\
\hline $2.1000 E+02$ & $2.335 E-23$ & $0.000 E+00$ \\
\hline $2.2000 E+02$ & $5.953 E-24$ & $0.000 E+00$ \\
\hline $2.3000 E+02$ & $1.517 E-24$ & $0.000 E+00$ \\
\hline $2.4000 E+02$ & $3.867 E-25$ & $0.000 \mathrm{E}+00$ \\
\hline $2.5000 E+02$ & $9.857 \mathrm{E}-26$ & $0.000 \mathrm{E}+00$ \\
\hline $2.6000 E+02$ & $2.513 E-26$ & $0.000 E+00$ \\
\hline $2.7000 E+02$ & $6.404 \mathrm{E}-27$ & $0.000 E+00$ \\
\hline $2.8000 E+02$ & $1.632 \mathrm{E}-27$ & $0.000 \mathrm{E}+00$ \\
\hline $2.9000 E+02$ & $4.161 E-28$ & $0.000 E+00$ \\
\hline $3.0000 E+02$ & $1.060 \mathrm{E}-28$ & $0.000 E+00$ \\
\hline $3.1000 \mathrm{E}+02$ & $2.703 E-29$ & $0.000 E+00$ \\
\hline $3.2000 \mathrm{E}+02$ & $6.890 E-30$ & $0.000 E+00$ \\
\hline $3.3000 \mathrm{E}+02$ & $1.756 \mathrm{E}-30$ & $0.000 E+00$ \\
\hline $3.4000 E+02$ & $4.476 \mathrm{E}-31$ & \\
\hline
\end{tabular}




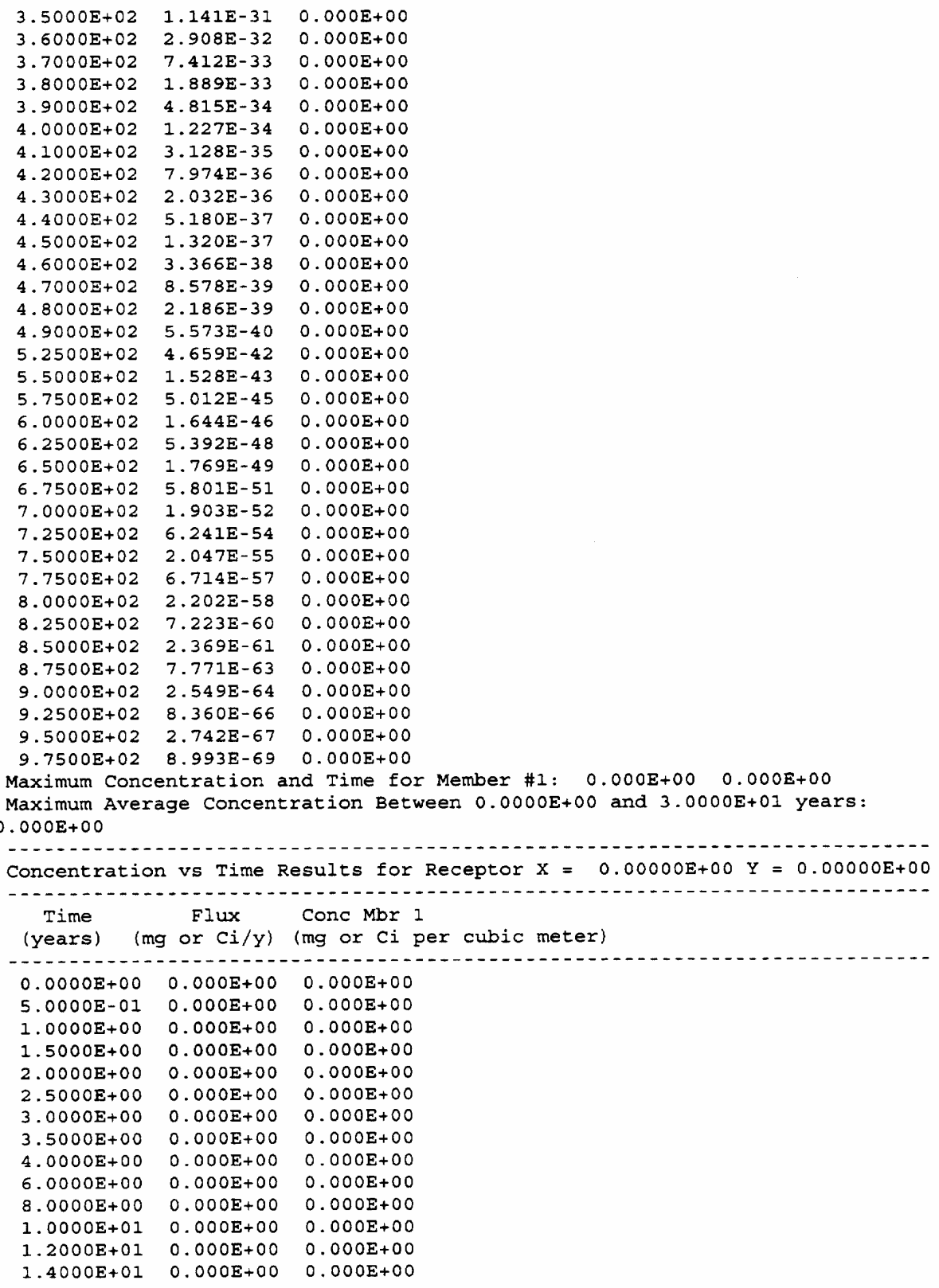




\begin{tabular}{|c|c|c|}
\hline $6000 E+01$ & $O E+00$ & +00 \\
\hline $.8000 E+01$ & $0.000 \mathrm{E}+00$ & $0.0005+00$ \\
\hline 01 & $.000 E+00$ & $0.000 \mathrm{E}+00$ \\
\hline$E+01$ & $0.000 \mathrm{E}+00$ & $0.000 \mathrm{E}+00$ \\
\hline $4000 \mathrm{E}+01$ & $0.000 \mathbf{E}+00$ & $0.000 \mathrm{E}+00$ \\
\hline $.6000 \mathrm{E}+01$ & $0.000 E+00$ & $0.000 E+00$ \\
\hline $2.8000 E+01$ & $0.000 E+00$ & $0.000 E+0$ \\
\hline $3.4000 E+01$ & $0.000 \mathrm{E}+00$ & $0.000 \mathrm{E}+\mathrm{C}$ \\
\hline $3.8000 \mathrm{E}+01$ & $0.000 E+00$ & $0.000 \mathrm{E}+$ \\
\hline $.2000 E+01$ & $0.000 \mathrm{E}+00$ & 00 \\
\hline $.6000 \mathrm{E}+01$ & $0.000 \mathrm{E}+00$ & $0.000 \mathrm{E}+00$ \\
\hline+01 & $0.000 \mathrm{E}+00$ & $0.000 E+00$ \\
\hline .4000 & $2.095 \mathrm{E}-04$ & $E-12$ \\
\hline $5.8000 \mathrm{E}+01$ & $1.569 E-05$ & $3 E-11$ \\
\hline $6.2000 E+01$ & $1.175 \mathrm{E}-06$ & 1.00 \\
\hline $6.6000 E+01$ & $8.805 E-08$ & $E-12$ \\
\hline $7.0000 E+01$ & $6.595 E-09$ & $a-12$ \\
\hline 7.400 & $E-10$ & $2-12$ \\
\hline+01 & 3.96 & $E-13$ \\
\hline+01 & $8-16$ & $E-13$ \\
\hline 9.500 & E-16 & $E-13$ \\
\hline 1.0000 & $7.917 E-17$ & $E-14$ \\
\hline 1.050 & 3.99 & $E-14$ \\
\hline 1.1000 & 2.018 & -14 \\
\hline 1.150 & -17 & -15 \\
\hline 1.2000 & -18 & -15 \\
\hline 1.2500 & 2.59 & -15 \\
\hline I. $3000 \mathrm{~F}$ & -18 & $E-15$ \\
\hline 1.35001 & -19 & -16 \\
\hline 1.4000 & $8-19$ & $:-16$ \\
\hline 1.45 & 1.687 & $E-16$ \\
\hline 1.5000 & 8.51 & $E-17$ \\
\hline $1.5500 \mathrm{E}+02$ & 4.300 & $E-17$ \\
\hline $1.6000 \mathrm{E}+02$ & $2.171 E-20$ & $2-17$ \\
\hline I. $6500 \mathrm{E}+02$ & $E-20$ & -17 \\
\hline $1.7000 \mathrm{E}+02$ & $z-21$ & -18 \\
\hline $1.7500 \mathrm{E}+02$ & 2.7 & -18 \\
\hline 1.800 & -21 & -18 \\
\hline 1.850 & 7.121 & 8.35 \\
\hline 1.900 & $3.595 E-22$ & -19 \\
\hline $1.9500 \mathrm{E}+02$ & $1.815 \mathrm{E}-22$ & -19 \\
\hline $2.1000 E+02$ & $.335 \mathrm{E}-23$ & -20 \\
\hline $2.2000 \mathrm{E}+02$ & $.953 E-24$ & $2-21$ \\
\hline $2.3000 E+02$ & $8-24$ & $8-21$ \\
\hline $2.4000 E+02$ & $3.867 E-25$ & 4. $242 E-22$ \\
\hline 2.500 & $9.857 E-26$ & 1.04 \\
\hline $2.6000 \mathrm{E}+02$ & $2.513 E-26$ & 2.56 \\
\hline $2.7000 E+02$ & $6.404 E-27$ & -24 \\
\hline $2.8000 E+02$ & $1.632 \mathrm{E}-27$ & -24 \\
\hline $2.9000 E+02$ & $4.161 E-28$ & $2-25$ \\
\hline $3.0000 E+02$ & $.060 E-28$ & $8.849 E-26$ \\
\hline $3.1000 E+02$ & $.703 E-29$ & $2.126 E-26$ \\
\hline $3.2000 E+02$ & $.890 \mathrm{E}-30$ & $5.091 E-27$ \\
\hline 3.3000 & $1.756 \mathrm{E}-30$ & $1.216 \mathrm{E}-27$ \\
\hline .4000 & $4.476 E-31$ & $2.898 E-28$ \\
\hline 5000 & $1.141 \mathrm{E}-31$ & $6.889 E-29$ \\
\hline 6000 & $2.908 \mathrm{E}-32$ & $1.634 \mathrm{E}-29$ \\
\hline
\end{tabular}




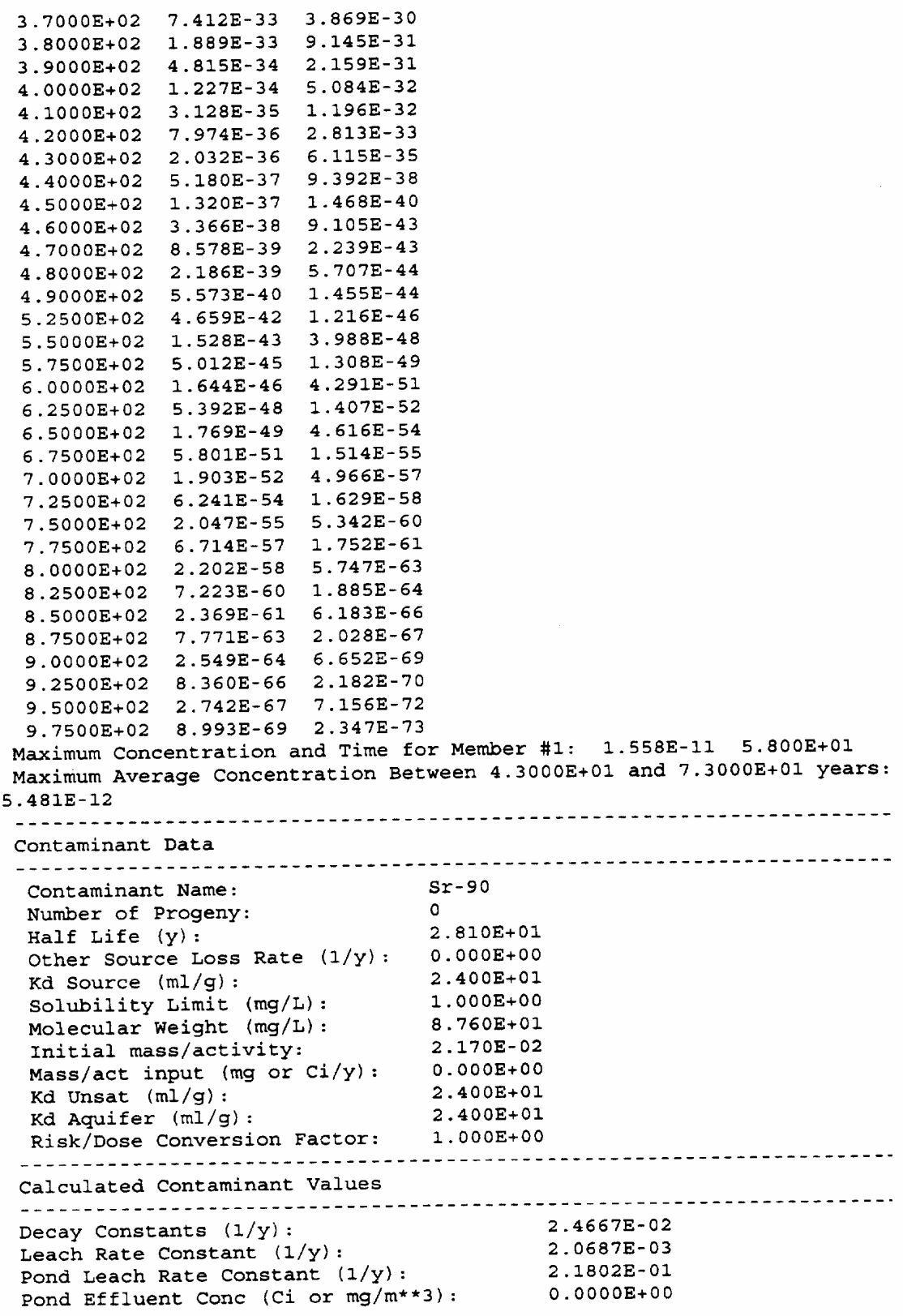




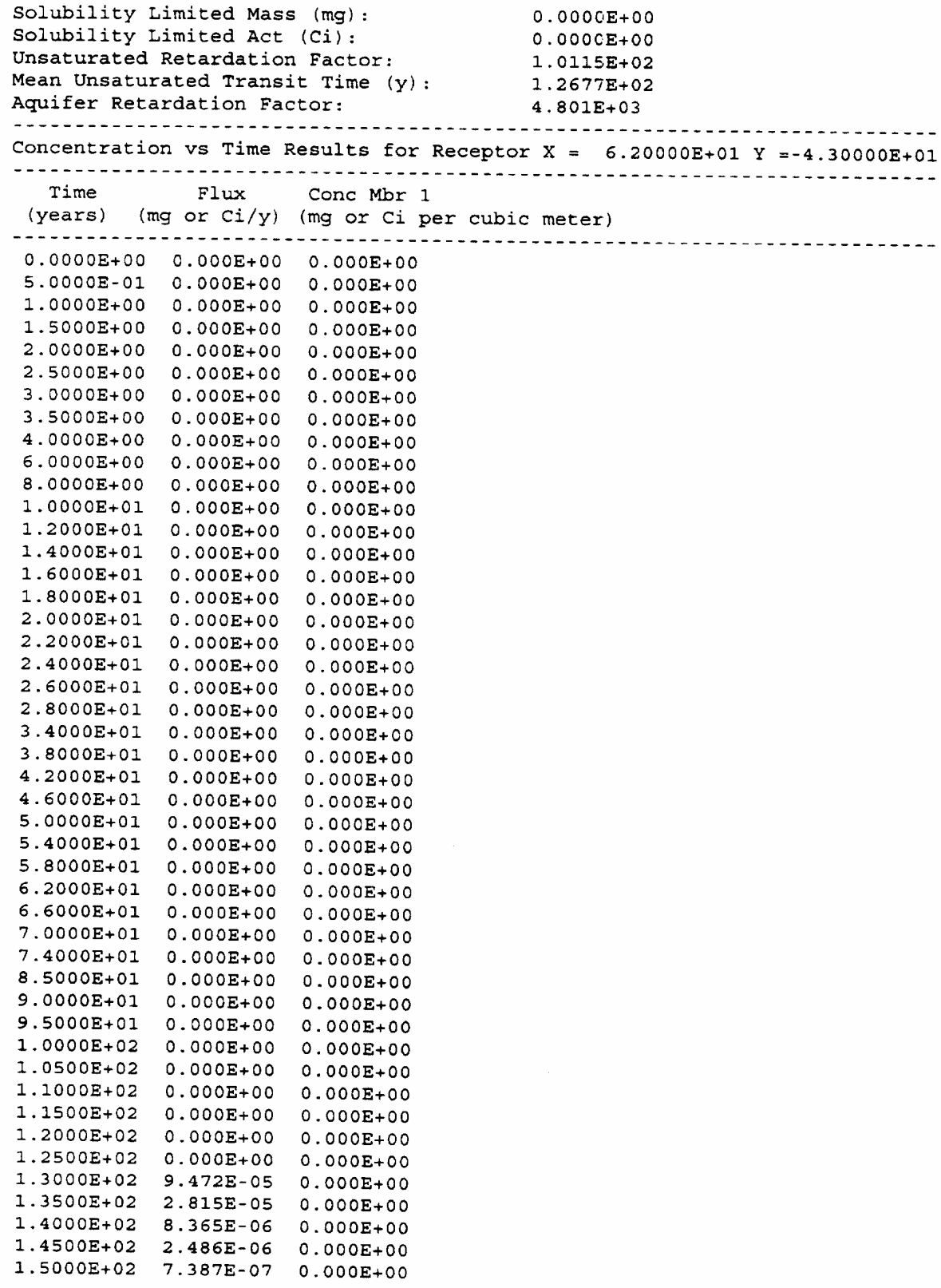




\begin{tabular}{|c|c|c|}
\hline & $2.195 E-07$ & $\mathrm{E}+00$ \\
\hline & $6.523 E-08$ & $0.000 E+00$ \\
\hline 02 & $.695 E-10$ & $0.000 E+00$ \\
\hline $1.7000 E+02$ & $3.233 E-10$ & $.000 E+00$ \\
\hline $1.7500 E+02$ & $2.828 \mathrm{E}-10$ & $0.000 \mathrm{E}+00$ \\
\hline $1.8000 \mathrm{E}+02$ & $2.474 \mathrm{E}-10$ & $0.000 E+00$ \\
\hline $1.8500 \mathrm{E}+02$ & $2.165 E-10$ & $0.000 E+00$ \\
\hline $1.9000 E+02$ & $1.894 \mathrm{E}-10$ & $0.000 \mathrm{E}+00$ \\
\hline $1.9500 E+02$ & $1.657 \mathrm{E}-10$ & $0.000 E+00$ \\
\hline 2.100 & $1.110 E-10$ & $0.000 E+00$ \\
\hline 2.200 & $8.492 E-11$ & $1.490 E-28$ \\
\hline $2.3000 E+02$ & $6.500 \mathrm{E}-11$ & $9 E-27$ \\
\hline $2.4000 E+02$ & $4.975 E-11$ & $E-25$ \\
\hline $2.5000 \mathrm{E}+02$ & $3.808 \mathrm{E}-11$ & $E-24$ \\
\hline $2.6000 E+02$ & $2.915 E-11$ & $E-23$ \\
\hline 2.700 & $2.231 E-11$ & $6.690 \mathrm{E}-23$ \\
\hline 2.80 & $1.707 \mathrm{E}-11$ & $2.944 \mathrm{E}-22$ \\
\hline 2.90 & $1.307 \mathrm{E}-11$ & $E-21$ \\
\hline 3.00 & $1.000 E-11$ & $E-21$ \\
\hline 3.10 & $7.656 \mathrm{E}-12$ & $E-21$ \\
\hline 3.20 & $5.860 \mathrm{E}-12$ & $E-20$ \\
\hline 3.30 & $4.485 \mathrm{E}-12$ & $E-20$ \\
\hline+02 & $3 E-12$ & $5 E-20$ \\
\hline 3.50 & $2.628 E-12$ & $E-19$ \\
\hline 3.60 & $2.011 \mathrm{E}-12$ & $E-19$ \\
\hline 3.70 & $1.539 E-12$ & $E-19$ \\
\hline 3.80 & $1.178 \mathrm{E}-12$ & $E-19$ \\
\hline 3.90 & $9.018 \mathrm{E}-13$ & $E-19$ \\
\hline 4.0 & $6.903 E-13$ & $E-19$ \\
\hline 4.100 & 5.28 & $E-19$ \\
\hline 4.20 & 4.0 & $E-18$ \\
\hline 4.30 & $3.095 E-13$ & $E-18$ \\
\hline 4.40 & $.369 E-13$ & $E-18$ \\
\hline 4.50 & E-13 & $E-18$ \\
\hline 4.60 & -13 & $E-18$ \\
\hline 4.70 & 1.06 & $E-18$ \\
\hline 4.80 & 8.13 & -18 \\
\hline 4.90 & $6.223 \mathrm{E}-14$ & $E-18$ \\
\hline 5.25 & $.441 E-14$ & $E-18$ \\
\hline 5.50 & $1.251 E-14$ & $E-18$ \\
\hline 5.75 & $3 E-15$ & $E-18$ \\
\hline 6.00 & -15 & $3 E-18$ \\
\hline 6.25 & 1.68 & $E-18$ \\
\hline 6.50 & $8.634 \mathrm{E}-16$ & -19 \\
\hline $6.7500 \mathrm{E}+02$ & $4.425 \mathrm{E}-16$ & -19 \\
\hline+02 & $2.268 \mathrm{E}-16$ & $E-19$ \\
\hline+02 & $1.162 \mathrm{E}-16$ & $1 E-19$ \\
\hline .5 & $.958 \mathrm{E}-17$ & $14 E-19$ \\
\hline 7.75 & $3.053 \mathrm{E}-17$ & $31 E-19$ \\
\hline 8.00 & $1.565 \mathrm{E}-17$ & $2 E-20$ \\
\hline 8.250 & $.021 E-18$ & $3 E-20$ \\
\hline $8.5000 \mathrm{E}+02$ & $.111 E-18$ & $50 E-20$ \\
\hline $8.7500 E+02$ & $2.107 E-18$ & $O E-20$ \\
\hline $9.0000 \mathrm{E}+02$ & $1.080 \mathrm{E}-18$ & $1.322 \mathrm{E}-20$ \\
\hline $9.2500 \mathrm{E}+02$ & $5.535 \mathrm{E}-19$ & $8.041 E-21$ \\
\hline 9.5 & $2.837 E-19$ & $4.849 E-21$ \\
\hline $9.7500 \mathrm{E}+02$ & $1.454 \mathrm{E}-19$ & $2.899 E-21$ \\
\hline
\end{tabular}




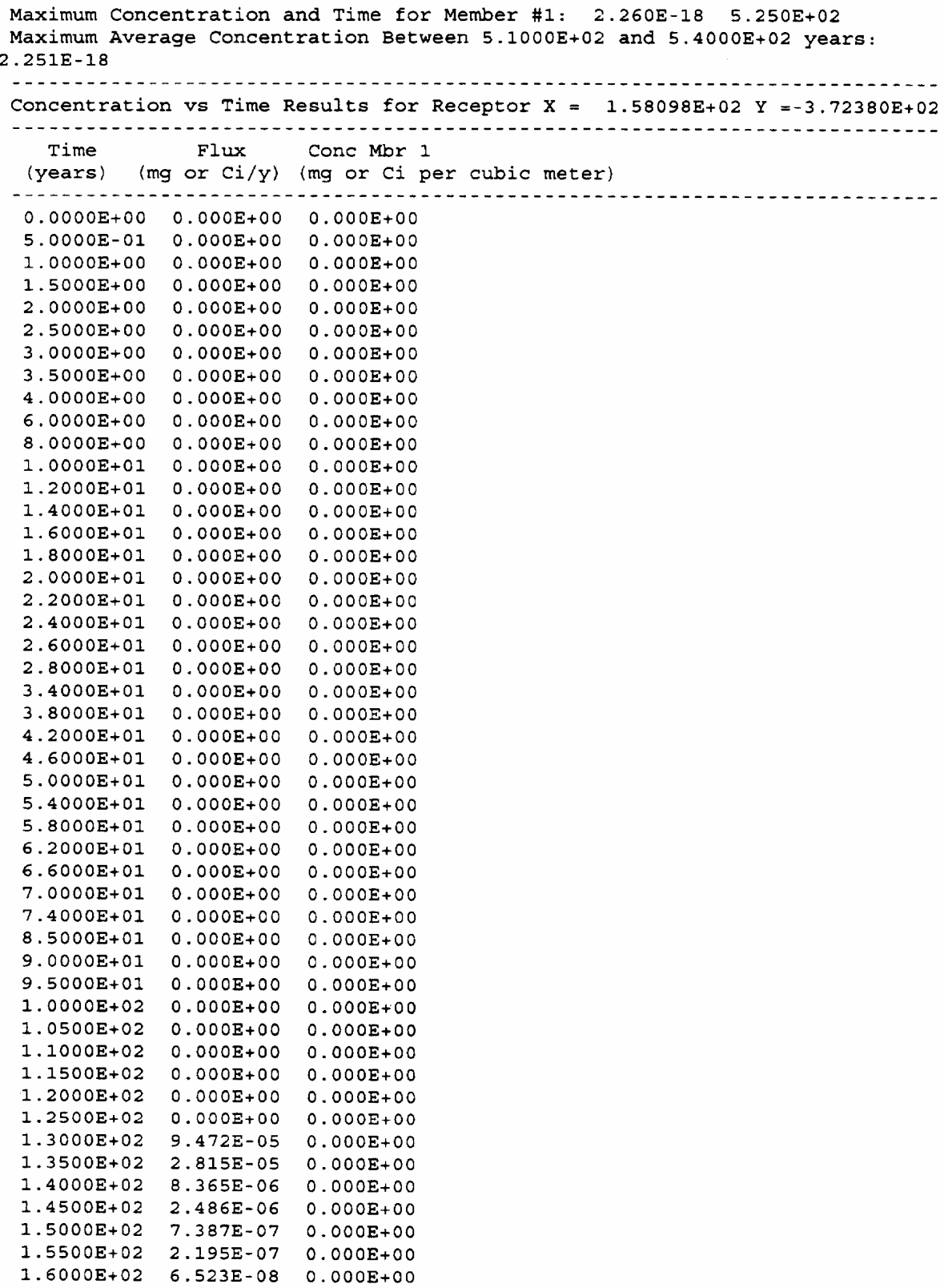




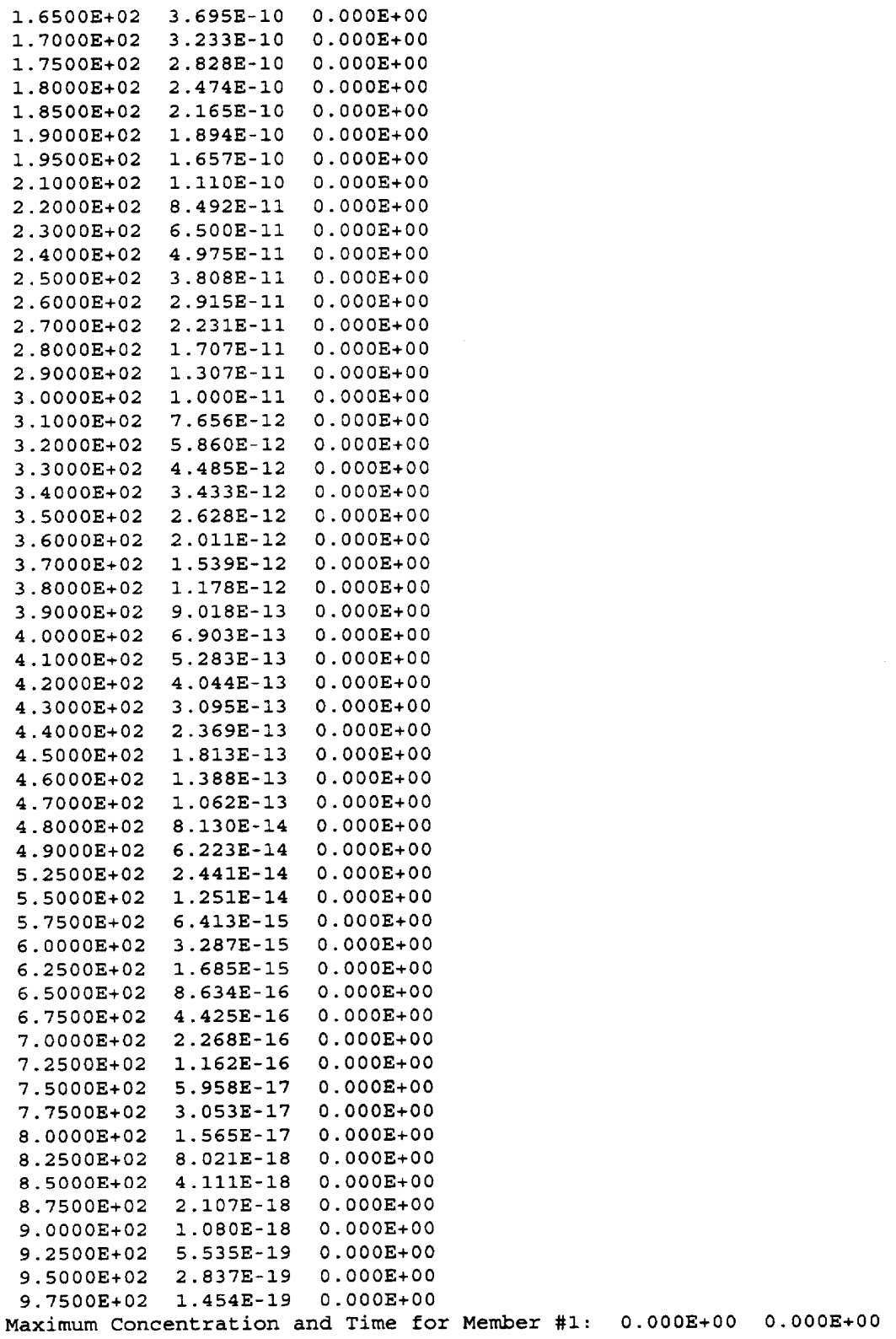




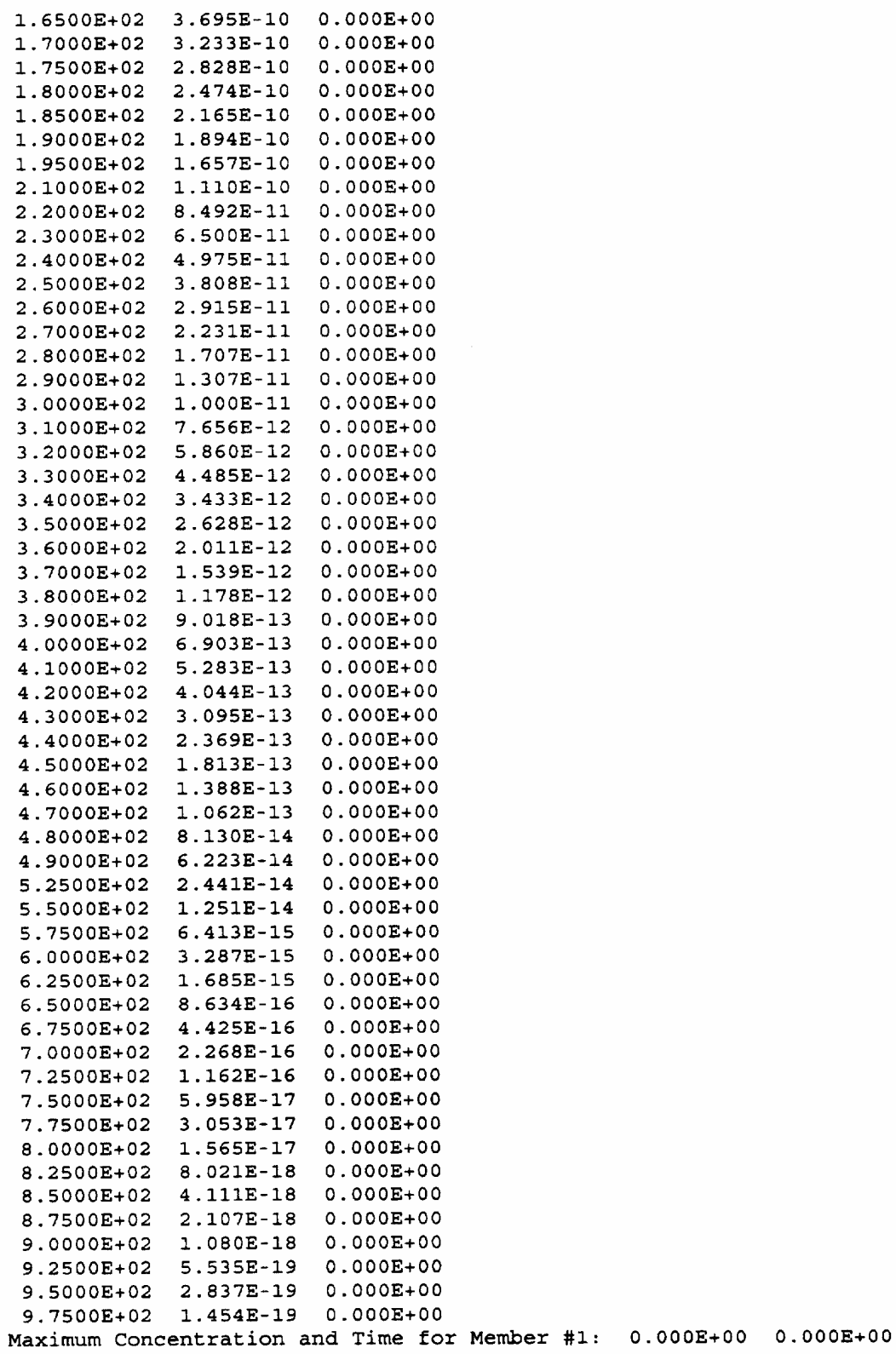




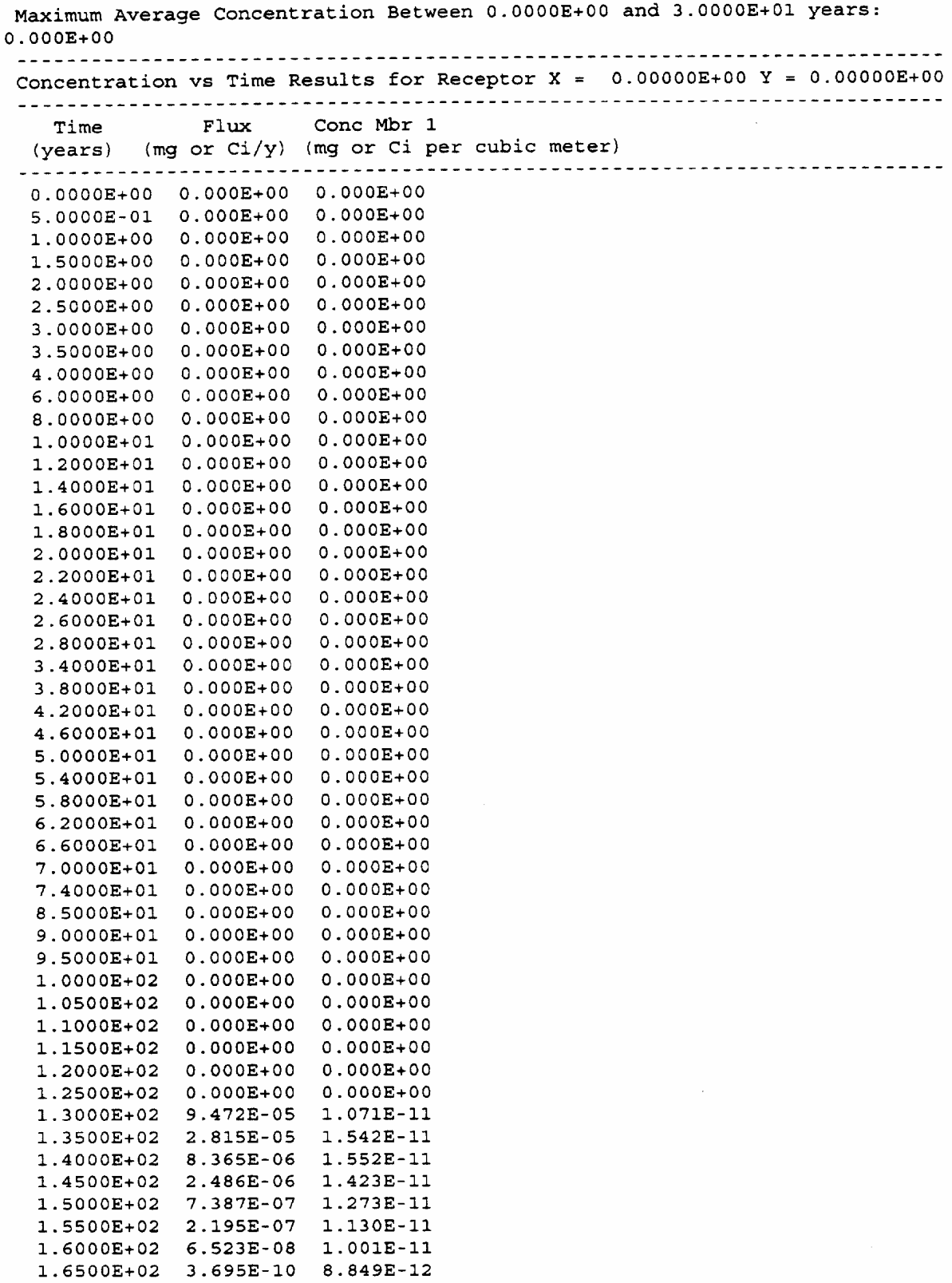




$$
\begin{array}{lll}
1.7000 E+02 & 3.233 E-10 & 7.822 E-12 \\
1.7500 E+02 & 2.828 E-10 & 6.915 E-12 \\
1.8000 E+02 & 2.474 E-10 & 6.112 E-12 \\
1.8500 E+02 & 2.165 E-10 & 5.403 E-12 \\
1.9000 E+02 & 1.894 E-10 & 4.776 E-12 \\
1.9500 E+02 & 1.657 E-10 & 4.222 E-12 \\
2.1000 E+02 & 1.110 E-10 & 2.916 E-12 \\
2.2000 E+02 & 8.492 E-11 & 2.279 E-12 \\
2.3000 E+02 & 6.500 E-11 & 1.781 E-12 \\
2.4000 E+02 & 4.975 E-11 & 1.391 E-12 \\
2.5000 E+02 & 3.808 E-11 & 1.087 E-12 \\
2.6000 E+02 & 2.915 E-11 & 8.495 E-13 \\
2.7000 E+02 & 2.231 E-11 & 6.637 E-13 \\
2.8000 E+02 & 1.707 E-11 & 5.185 E-13 \\
2.9000 E+02 & 1.307 E-11 & 4.050 E-13 \\
3.0000 E+02 & 1.000 E-11 & 3.162 E-13 \\
3.1000 E+02 & 7.656 E-12 & 2.468 E-13 \\
3.2000 E+02 & 5.860 E-12 & 1.925 E-13 \\
3.3000 E+02 & 4.485 E-12 & 1.501 E-13 \\
3.4000 E+02 & 3.433 E-12 & 1.169 E-13 \\
3.5000 E+02 & 2.628 E-12 & 9.095 E-14 \\
3.6000 E+02 & 2.011 E-12 & 7.071 E-14 \\
3.7000 E+02 & 1.539 E-12 & 5.490 E-14 \\
3.8000 E+02 & 1.178 E-12 & 4.258 E-14 \\
3.9000 E+02 & 9.018 E-13 & 3.298 E-14 \\
4.0000 E+02 & 6.903 E-13 & 2.551 E-14 \\
4.1000 E+02 & 5.283 E-13 & 1.970 E-14 \\
4.2000 E+02 & 4.044 E-13 & 1.520 E-14 \\
4.3000 E+02 & 3.095 E-13 & 1.171 E-14 \\
4.4000 E+02 & 2.369 E-13 & 9.005 E-15 \\
4.5000 E+02 & 1.813 E-13 & 6.915 E-15 \\
4.6000 E+02 & 1.388 E-13 & 5.303 E-15 \\
4.7000 E+02 & 1.062 E-13 & 4.062 E-15 \\
4.8000 E+02 & 8.130 E-14 & 3.107 E-15 \\
4.9000 E+02 & 6.223 E-14 & 2.372 E-15 \\
5.2500 E+02 & 2.441 E-14 & 9.141 E-16 \\
5.5000 E+02 & 1.251 E-14 & 4.584 E-16 \\
5.7500 E+02 & 6.413 E-15 & 2.283 E-16 \\
6.0000 E+02 & 3.287 E-15 & 1.130 E-16 \\
6.2500 E+02 & 1.685 E-15 & 5.559 E-17 \\
6.5000 E+02 & 8.634 E-16 & 2.721 E-17 \\
6.7500 E+02 & 4.425 E-16 & 1.326 E-17 \\
7.0000 E+02 & 2.268 E-16 & 6.433 E-18 \\
7.2500 E+02 & 1.162 E-16 & 3.109 E-18 \\
7.5000 E+02 & 5.958 E-17 & 1.497 E-18 \\
7.7500 E+02 & 3.053 E-17 & 7.190 E-19 \\
8.0000 E+02 & 1.565 E-17 & 3.442 E-19 \\
9.2500 E+02 & 8.021 E-18 & 1.644 E-19 \\
9.50000 E+02 & 4.111 E-18 & 7.830 E-20 \\
9.7500 E+02 & 1.454 E-19 & 1.867 E-21
\end{array}
$$

